\title{
PRINCIPAIS LINHAS DA RESPONSABILIDADE CIVIL NO DIREITO BRASILEIRO CONTEMPORÂNEO
}

\author{
MAIN LINES ON TORTS IN CONTEMPORARY BRAZILIAN LAW
}

Teresa Ancona Lopez

\begin{abstract}
Resumo:
A evolução da responsabilidade civil da culpa ao risco. consagrada com a vigência do novo Código Civil brasileiro, sob a ótica da autora, associada do Departamento de Direito Civil, desta Academia de Direito.
\end{abstract}

Palavras-chave: Lei n. 10.406 de 10.01.2002. Responsabilidade Civil. Teoria do abuso do Direito. Responsabilidade sancionatória. Responsabilidade reparatória. Responsabilidade subjetiva e objetiva.

\begin{abstract}
:
The evolution of torts, from guilt to risk, inserted in the new Brazilian Civil Code, according to the point of view of the author, Associate Professor of the Civil Law Department of this I aw Academy.
\end{abstract}

Keywords: Law n. 10.406, of 10th January 2002. Torts. Abuse of Rights Doctrine. Punitive Liability. Restoring I.iability. Subjective and Objective Liability.

1. Da culpa ao risco

Com a entrada em vigor do novo Código Civil brasileiro (Lei n. 10.406, de 10 de janeiro de 2002), completa-se o ciclo de evolução da responsabilidade civil da culpa ao risco iniciado de maneira esporádica e, ao mesmo tempo. surpreendente pela promulgação do Dec. n. 2.681, de 07 de dezembro de 1912, o qual, ao regular a responsabilidade civil das estradas de ferro (que acabou se estendendo, e ainda se aplicando, no que não-contrariar a nossa legislação. para todo tipo de transporte terrestre), adotou expressamente a responsabilidade civil objetiva em scu art. 17, no qual há a presunção absoluta de responsabilidade, somente sendo elidida pela força maior ou culpa do viajante. não concorrendo a culpa da estrada, e, da mesma forma, no art. 26, que objetivamente impõe a responsabilidade à estrada de ferro pelos danos causados aos proprietários marginais, somente liberando essa responsabilidade a infração direta do proprietário atingido pelo evento danoso.

Professora Livre-Docente Associada do Departamento de Direito Civil da Faculdade de Direito da Universidade de São Paulo. Advogada em São Paulo. teresa.ancona@uol.com.br- 
Portanto, foi o Direito brasileiro ousado e progressista ao acompanhar os perigos da nova sociedade comandada por máquinas de todos os tipos. O Código Civil, de 1916, também abraçara a teoria objetiva no art. 1.529 e a presunção de culpa nos arts. 1.527 e 1.528. Da mesma forma, leis esparsas, como a lei de acidentes do trabalho, as leis da responsabilidade civil das aeronaves, da responsabilidade civil por danos nucleares, da responsabilidade civil das agências de empregados, etc, que começavam a surgir a partir da década de 40. Mas, como sabemos, o grande passo rumo ao risco da atividade como fundamento da responsabilidade do causador do dano, veio com a promulgação do Código de Defesa do Consumidor (Lei n. 8.078, de 11 de setembro de 1990), tido como uma das leis mais modernas e protetivas, servindo de inspiração a leis de outros países, como a lei argentina de 1993.'

Com o advento do Código ('ivil, de 2002, há a adoção da teoria da culpa, como orientação geral (art. 186 e 927, caput), e a consagração da responsabilidade fundada no risco na cláusula geral que dá conteúdo ao parágrafo único do art. 927 . e que ressalta que também haverá obrigação de indenizar, independentemente de culpa, mas somente nos casos especificados em lei ou quando a atividade normalmente desenvolvida pelo autor do dano por sua natureza criar riscos.

Porém, antes de analisarmos as grandes linhas do ressarcimento do dano no Código Civil, de 2002, é preciso salientar que tanto a lei de responsabilidade civil pelos danos nucleares, quanto aquela que trata dos desastres ao meio ambiente, são normas que, segundo a maioria dos intérpretes, abraçaram a teoria do risco integral, não admitindo nem a excludente de força maior, que é aplicada até na responsabilidade pelos danos causados pelo Estado e seus agentes e concessionários, e que no Brasil é fundada na teoria_do risco administrativo, bem mais suave que as duas anteriores citadas (conforme art. $37, \S 6^{\circ}$ da Constituição Federal de 1988).

\section{Posição sistemática incensurável da matéria}

A primeira grande inovação foi a mudança sistemática da matéria. $\mathrm{O}$ Código Civil, de 2002, separou a noção de ato ilícito, ${ }^{2}$ tipificando-a na Parte Geral. e colocou a obrigação de indenizar dentro do Livro das Obrigações (Livro I. da Parte Especial, no título IX ) sob a epigrafe de "Responsabilidade Civil" subdividindo esse

Lei de Defensa Del Consumidor n. 24.240, de 15/X/1993, modificada pelas leis ns. 24.568, 24.787. 24.999 c pelo Dec. n. 2.089.

Ant. 186. "Aquuele que. por ação ou omissão voluntảia, neglig̣ência ou imprudência, violar direito e causar dano a outrem, ainda que exclusivamente moral, comete ato ilicito". Art. 187. "Também comete ato ilicito o titular de um direitu que, ao exercê-lo, excede manifestamentc os limites impostos pelo seu fim econômico ou social, pela boa-fé ou pelos bons costumes" 
título em dois capítulos: o Capítulo I que trata da "obrigação de indenizar", estando aí elencados os vários tipos de responsáveis pelos danos injustos; o Capítulo II trata propriamente "Da Indenização" ou seja, das várias maneiras de liquidação de reparação devida, sempre se coadunando com as hipóteses previstas.

Com a separação entre o ato ilícito e a responsabilidade civil, fica claro que o dano é requisito fundamental da responsabilidade civil, tanto que a indenização. em princípio, mede-se pela extensão do dano (art. 944, caput), mas não do ato ilícito. Podemos ter ato ilícito sem dano (portanto, sem responsabilidade) como no caso de vizinhos que perturbando a paz de outros e que não deverão necessariamente pagar perdas e danos, somente cessar suas interferências injustas ou do art. 940 do Código Civil, que determina que aquele que demanda por dívida já paga ficará obrigado a pagar ao devedor o dobro do que houver cobrado ou o equivalente do que dele exigir. Por outro lado, poderá trazer responsabilidade civil sem ato ilícito, como na hipótese do art. 929 do Código Civil.

Finalmente, acompanhando a nova elogiável posição sistemática temos o art. 927 que em seu "caput" determina que aquele que por ato ilícito (e ai se refere aos arts. 186 e 187) causar dano a outrem fica obrigado a repará-lo. Sendo que no seu parágrafo único prevê a obrigação de indenizar para casos em que a atividade do autor do dano ponha risco direitos de outrem, ou seja, a responsabilidade civil que emerge dos atos lícitos (risco da atividade).

De outro lado, dentro de toda a coerência e seguindo a tendência mais moderna do Direito Civil, desvinculou, nosso legislador, a noção de culpa da de ato ilícito (ato antijurídico).

Assim. está consagrada no art. 187, da Parte Geral, a teoria objetiva do abuso do direito. ou seja. também comete ato ilícito "o titular de um direito que, ao exercê-lo, excede manifestamente os limites impostos pelo seu fím econômico ou social. pela boa-fé ou pelos bons costumes"

Portanto, com essa sistematização, a noção do abuso do direito que já de há muito havia extravasado o campo da responsabilidade civil, hoje é cláusula geral, que pode ser aplicada em todas as situações jurídicas que se amoldarem ao conceito aberto do art. 187, seja qual for o ramo do Direito que dele necessite se utilizar. É o que veremos a seguir. 
Como afirma Heloísa Carpena, ${ }^{3}$ em obra primorosa sobre a matéria, "dentro das chamadas teorias humanizadoras do Direito, a teoria do abuso do direito pode ser destacada como aquela que melhor expressa o fenomeno da constitucionalização do Direito Civil (...). Na ótica solidarista, trazida pela nova ordem constitucional, os direitos subjetivos se relativizam e os limites ao seu exercício passam a ser estahelecidos por uma tábua de valores afinados com o primado da dignidade da pessoa humana, um dos fundamentos do nosso sistema juridico"

Portanto, com o novo sistema de valores que começou formalmente, em 1988, e que foi abraçado pelo Código Civil, de 2002 (além de leis esparsas como o CDC, ECA, Lei das Locações, Lei de Direito do Autor, etc), consagra a eticidade (boa-fé e bons costumes) e a socialidade (função social da propriedade, do contrato, finalidade social do exercício do direito) como princípios, princípios esses que perpassam a nova ordem civil inteira. Nesse diapasão, vem adotar a teoria do abuso do direito que tem em sua essência a verificação de quais são os limites impostos ao exercício dos direitos subjetivos. É conseqüência da adoção da concepção relativista do direito, reação ao absolutismo. voluntarismo e individualismo que impregnavam ainda o Código Civil, de 1916, e o colocavam fora da realidade social atual, exigindo a interpretação jurisprudencial sempre atualizada e a edição de legislação esparsa em grande quantidade, para complementar ou "remendar" o espírito do antigo Código.

A teoria do abuso do direito é construção doutrinária nova, do século XX, é apenas "aparentada" à doutrina medieval dos atos de emulação (que são aqueles que no seu exercício, somente visam prejudicar a outrem, sem tirar nenhuma vantagem nisso). Os brocardos sunumum jus, summa injuria ou neminem laedit qui suo jure utitur, que ainda são usados, não constituíam uma teoria. Apenas havia no Direito Romano o pressentimento do desvio da finalidade do direito. ${ }^{S}$

O art. 187 determina que também comete ato ilícito o titular de um direito que ao exercê-lo excede manifestamente os limites impostos pelo seu fim econômico e social, pela boa-fé ou pelos bons costumes. ${ }^{6}$

3 CARPENA. Hetoisa. Abuso de direito nos contratos de consumo. Rio de Janeiro/São Paulo: Renovar. 2001. p. 1 .

- GOMES, Orlando. Introdução ao direito civil. 12. ed. Rio de Janeiro: Forense, 1996. p. 131.

Id. Ibid.

6 "Direito Civil e processual civil. Recurso especial. Embargos de declaração interpostos perante o Tribunal de origem. Ausência de omissão. contradição ou obscuridade. Propositura de execução por instituição financeira sem a devida cautela na verificação da regularidade do contrato bancário. Abuso de direito. Reexame de provas. Alegação de divergência jurisprudencial. Ausência de comprovação de similitude entre os julgados confrontados. Indenização por danos morais. Condenação em valor menor que $n$ 
Portanto, no dispositivo em examc há três limites ao exercício do direito subjetivo (não ao direito subjetivo) que não se confundem. São três conceitos jurídicos diferentes em uma mesma regra, ou melhor, três cláusulas gerais diferentes e limitativas da conduta do titular do direito. No ato abusivo há violação funcional do direito (social), de sua finalidade e de seu espírito.

Como bem demonstra Heloisa Carpena, tanto no ato ilícito, quanto no abuso, há uma atuação fora do direito - é o sem direito, o antijurídico. " $A$ antijuridicidade pode resultur tanto da violação da forma como do sentido valorativo dos direitos" "Há, assim, autonomia do ilícito vindo do abuso do direito em relação ao ato ilicito.

O conceito de ilicitude (abuso do direito e também ato ilicito) não se confunde com a noção de culpa. Ilícito é o que é contra o direito. Diz respeito ao ato em si, objetivamente considerado, desligado da intenção do sujeito. $\mathrm{O}$ ato em abuso do direito tem conteúdo ilegítimo ${ }^{9}$ e a sua aferição independe de culpa, basta que o ato, no exercício do direito, exceda os limites impostos a esse exercício. Nas Jornadas do STJ, ${ }^{10}$ o enunciado n. 37 prescreve que "a responsabilidade civil decorrente do abuso do direito independe de culpa, e fundamenta-se no critério objetivo-finalistico, conforme interpretação doutrinária" "A culpa pode ser pressuposto da responsabilidade civil, mas jumais requisito da ilicitude que respeita ao próprio ato" ${ }^{12}$ Em suma, a concepção do abuso do direito é objetiva. "Não é necessária a consciência de se atingir, com seu exercicio, a bou-fé. os bons costumes ou o fim social ou econômico do direito conferido; basta yue os atinja" 13

Como já salientamos, o Código Civil, de 2002, separa sistematicamente o ato ilícito (Parte Geral) da obrigação de indenizar (Parte Especial - Obrigações), pois o

pleiteado. Sucumbência reciproca. Honorários advocatícios. Despesas processuais. Rejeitam-se os embargos de declaração quando ausente omissão, contradição ou obscuridade a ser sanada. A instituição financeira, ao propor, contra terceiro de boa-fé, ação de execução fundada em contrato bancário celebrado sem as devidas cautelas, age com abuso de direito e responde pelos prcjuizos causados. É inviável, em sede de recurso especial, novo delineamento dos fatos discutidos no processo. (....)" (STJ, RESP 650793/PE, Relatora Ministra Nancy Andrighi, Terceira Turma, julgado em 14/09/2004, publicado em 04/10/2014. (irifos nossos).

CARPIVA. Heloisa. Op. cit., p. 57 e segs.

Id. Ibid.. p. 58.

- Dispõe o art. 334 do Código Civil português: "É ilegítimo o exercicio de um direito, quando o titular exceda manilestamente os limites impostos pela boa-fé, pelos bons costumes ou pelo fim social ou econòmico desse direito"

1.. ROSADO, Ruy (Coord.). Jomadas de Direito Civil. Centro de Estudos Judiciários do Conselho de Justị a Federal, setembro de 2002.

1 NERY, Nelson. Código civil anorado. São Paulo: Revista dos Tribunais. 2003.

12 CARPENA, Heloisa. Op. cit. p. 60.

13 LiMA. F. A. Pires de: VARELA. J. M. Antunes. Código civil anorado. Portugal: Coimbra Editora l.tda., 1967. v. 1, p. 217. 
ilícito que dá conteúdo ao ato abusivo pode gerar outros tipos de sanções, além da indenização, caso haja clano indenizável. Exemplo de ato abusivo sem dano é o de propaganda abusiva (art. 37. $\S 2^{\circ}, C D C$ ). Podemos lembrar também, com fundamento no Código de Defesa do Consumidor, que as cláusulas abusivas em contratos de consumo têm como sanção a nulidade. já que contra a boa-fé, a eqüidade e a função social do contrato. $\mathrm{O}$ abuso do poder familiar pode levar à sua perda por sentença judicial. Também nos direitos de vizinhança vários exemplos podem ser lembrados: como as interferências (sonoras, poluentes, etc) prejudiciais à segurança. ao sossego e à saúde dos que habitam certo imóvel, e que são provocados pela utilização anormal (com desvio da finalidade social) de propriedade vizinha e que dão ao proprietário ou possuidor desse prédio o direito de fazer cessá-las. Em alguns casos, não há obrigação de indenizar, como na hipótese de levantar muros além do permitido ou abrir janelas contra as regras de vizinhança. Nesses casos a sanção consiste em desfazer o que foi feito. ${ }^{14}$

Ressalte-se. porém, que o abuso do direito, como cláusula geral, só gera o dever de indenizar quando no seu exercício seu titular tenha causado dano a outrem. É caso de responsabilidade extracontratual fundado no caput do art. 927 do Código Civil. Portanto, a sanção ao uso abusivo de um direito subjetivo é a reparação do dano, pois se trata de ato ilícito e de natureza objetiva. Repita-se, independentemente de dolo ou culpa.

A avaliação do caráter abusivo do ato fica a cargo do juiz que deverá observar se o exercício desse direito excedeu manifestamente os limites impostos pelo seu fim econômico ou social, pela boa-fé ou pelos bons costumes.

Como já exposto anteriormente. a moderna construção doutrinária da teoria do abuso do direito é do século XX e a teoria dos atos de emulação, doutrina medieval, veio da França (começo do século XX), onde surgiu por construção jurisprudencial e também do Direito alemão onde, já em 1900, o BGB, no § 226, determinava que "o exercício de um direito é inadmissivel, se ele tiver por fim, exclusivo, causar dano a outrem" Nesse texto fica clara a idéia de abuso do direito como a prática de atos de emulação. que tem o objetivo exclusivo de causar dano a outrem, mesmo se em sua prática seu causador não aufira vantagens.

Porém, é importante ressaltar que na Doutrina francesa há duas correntes principais sobre a teoria do abuso do direito: a subjetiva, na qual o que se tem como abusivo é a intenção de prejudicar terceiro, mesmo quando não há nenhum interesse para seu autor. Podemos dizer que essa vertente consagra a teoria dos atos emulativos. É a mera intenção de prejudicar. Por outro lado. no critério objetivo, não se indaga a intenção mas examina-se o ato e o dano causado pelo abuso. A concepção objetiva

is Orlando Gomes acha que todo abuso deve causar dano, op. cit., p. I 35. 
alcançou seu auge com Josserand para quem haverá abuso do direito quando seu titular utilizá-lo em desacordo com a finalidade social para qual os direitos subjetivos foram concedidos, ou seja, devem ser usados de uma forma que se acomode ao interesse coletivo, obedecendo à sua finalidade, segundo o espírito da instituição. ${ }^{15}$

Essa visão objetiva dos atos em abuso do direito se distancia da antiga proibição dos atos de emulação que vinha com carga de subjetivismo. Na Itália, não existia, como não existe, no Código Civil norma geral (somente artigos específicos) sobre o abuso do direito mas a Jurisprudência e a Doutrina italianas adequaram o ordenamento aos novos valores constitucionais, principalmente com apoio no princípio de solidariedade social e da função social da propriedade, culminando com o reconhecimento de ser o exercício abusivo dos direitos ato ilícito ("ex vi" do art. 2.043 do Código Civil italiano), sempre que um direito subjetivo seja utilizado contra a função econômico-social para o qual ele existe e com a finalidade diferente daquela prevista pelo ordenamento. Finalmente, na jurisprudência recente italiana se estende a teoria ao direito de crédito com fundamento na cláusula geral de boa-fé, ampliando os meios de tutela além dos casos típicos de inadimplemento contratual. É. abuso do direito a violação de dever contratual de boa-fé. ${ }^{16}$

O abuso do direito como previsto no Direito brasileiro atual, e que tem como fonte o art. $334^{\circ}$ do Código Civil português, vem dessa interpretação objetiva, do uso do direito subjetivo, com vistas à finalidade e função dos institutos jurídicos e ainda o prestígio à boa-fé objetiva quando se tratar de relações contratuais. ${ }^{17}$

Por outro lado o art. 188, 1, $2^{\mathrm{a}}$ parte, prevê que não constituem atos ilícitos os praticados em legítima defesa ou no exercício regular de um direito. Trata-se de excludentes de ilicitude. Tanto que o "caput" do art. 927 somente faz referências aos arts. 186 e 187. como atos ilícitos. Será ilegítimo o exercício anormal ou irregular de um direito, podendo levar aquele que causou dano a obrigação de indenizar? ${ }^{18} /{ }^{19}$ Penso que sim; que também pode ser ato ilícito aquele praticado no exercício anormal de um

RODRIGUES, Silvio. Direito civil -- responsabilidade civil. 19. ed. São Paulo: Ed. Saraiva, 2002. v. 4, p. 43-49.

16 LEVAnTI, Sandra. Abuso del diritto. Diritto e Diritti Porlale Giuridico, junho de 2001. Consulta em $21 / 05 / 2004$.

17 Código Civil português, art. 334 - Abuso do direito "É ilegítimo o exercício de um direito, quando o titular exceda manifestamente os limites impostos pela boa-fé, pelos bons costumes ou pelo fim social ou econômico desse direito".

is Como é óbvio, muitas vezes o uso dos direitos causa incômodo às pessoas, mas é o uso normal ou exercicio legítimo (conforme a finalidade social do Direito), como no caso da penhora, do despejo, da ação possessória, do protesto legitimo de títulos de crédito, etc.

19 Código Civil alemão, § 226: "Divieto di atti emulativi" "I 'esercizio di un diritto é inammissibile, se può avere solo lo scopo di arrecare danno ad un altro (PATTI, Salvatorc. (Trad.). Códice Civile Tedesco. Milão: Ed. Giuffrè, 2005). 
direito, mas não é ato abusivo. Como, por exemplo, o excesso de legítima defesa no desforço pessoal (art. 1.210, $\S 1^{\circ}$ ). Em suma, a teoria do abuso do direito (finalista e funcional), como recepcionada pelo novo Código Civil, não tem nada a ver com a teoria construida pela interpretação "a contrario sensu", com fundamento no art. 160, I, in fine (do CC/16), redação agora repetida no art. 188, I, $2^{\text {a }}$ parte do Novo Código Civil. ${ }^{20}$ Ao contrário, o art. 187 do Código Civil tem como fonte direta o art. 334 do Código Civi] português, como dissemos.

Finalmente, ainda segundo Nery, além da obrigação de reparar danos morais e patrimoniais o ato ilícito abusivo deverá ser fulminado de nulidade nos termos do art. 166, VI (fraudar lei imperativa). ${ }^{21}$

4. As teorias que informam a responsabilidade civil no Código Civil brasileiro de 2002

4.1. Da responsabilidade sancionatória à responsabilidade reparatória

Começo fazendo uma série de considerações que acho básicas para o entendimento da matéria.

Com a intrada em vigor do novo Código Civil tivemos também a mudança de modelo, porquanto dentro da nova sistemática, em que os valores e princípios comandam, usa o legislador do recurso técnico das cláusulas gerais e dos conceitos jurídicos indeterminados que, dando estrutura ao novo ordenamento. determinam também um novo paradigma, ou seja, dentro do atual sistema aberto, que começa no Código de Defesa do Consumidor, esse novo paradigma é o juiz, e não mais o desatualizado texto frio da lei. Em outras palavras, as chamadas "cláusulas gerais" somente receberão seu conteúdo definitivo na hora da aplicação ao caso concreto, no momento da concretude. Ou seja, como todo sistema aberto, o Código Civil, de 2002, se instrumentaliza por meio dessas normas gerais e indeterminadas, formando um sistema dito incompleto, que somente se completará com a declaração do judiciário. Há. a partir de então, a atuação de duas vontades para que se chegue à integração da norma: a da lei e a do juiz.

20 Exemplos de atos abusivos: concorrência desleal, impedir direitos de visita dos avós, purgaçào da mora mais que três vezes, banco que retira dinheiro da conta do cliente para se autopagar de financiamento, desconsideração da personalidade juridica por abuso do dưeito. litigante de má-fé. abuso de autoridade por ... V. NERY, Velson. op. cit.; GOMES, Orlando. Introdução ao direito civil. 12. ed. Rio de Janeiro: Forense, 1996; STOCO. Rui. Tratado de responsabilidade civil. 5. ed. São Paulo: Revista dos Tribunais. 2001 ; VISINTINI. Giovanna. Trattato breve della responsahilita civile. 2. ed. Padovia: Cedam, 1999.

21 NERY, Nelson. op. cit., ('omentário ao an. 187. 
Sem dúvida, a participação do poder discricionário do julgador será enorme; porém, por outro lado, estamos diante de um sistema dúctil, que acompanhará a realidade social diuturnamente e, mais facilmente, conseguirá realizar os valores da função social, da ética e da eqüidade, enfim, da Justiça.

A outra série de considerações diz respeito à própria Teoria da Responsabilidade Civil atual, que tanto no Código Civil, de 2002, quanto já no Código de Defesa do Consumidor, está voltada, como em todo Direito Contemporâneo, para a proteção da vítima. A vítima é o centro da Responsabilidade Civil e não mais o ofensor, como no Direito vindo dos séculos XIX e XX, em que o voluntarismo e o individualismo eram princípios dominantes. Substitui-se a idéia de sanção pelo ilícito pela de reparação do dano injusto.

Dessa forma, a vitima ou sua família devem ser sempre ressarcidas e o Direito vai sempre arranjar um modo de indenizá-los (fique claro que indenizar significa tornar indene). Daí a necessidade de novas técnicas jurídicas, que impregnando a Responsabilidade Civil, caminharam no sentido da responsabilidade objetiva (chegando até ao risco integral), que cada vez mais está presente em todo o Direito Contemporâneo, o que teve como conseqüencia desenvolver e propagar o contrato de seguro de responsabilidade civil (danos a terceiros) para que seja repartido com toda a sociedade o quantum do prejuízo a ser ressarcido à vítima do dano.

4.2. Responsabilidade subjetiva. Responsabilidade Objetiva. Responsabilidade fundada no risco. Considerações gerais

Primeiramente, a responsabilidade subjetiva, fundada na culpa lato sensu, continua sendo a principal teoria informadora de nosso sistema. ${ }^{22}$ É o que se infere dos arts. 186 e 927, "caput" do CC/02. O parágrafo único desse artigo vem ressalvar o texto de seu "caput", pois, após afirmar que aquele que causar ato ilícito deverá reparar o dano, determina que essa obrigação existirá (também) no caso de atividade que ponha em risco os direitos de outrem. Temos, portanto. as duas teorias (subjetiva e objetiva) convivendo dentro do mesmo ordenamento, apesar do Código Civil ter se filiado, em princípio, à teoria da culpa. A responsabilidade fundada no risco somente serve aos casos que se amoldam aos termos do parágrafo único do art. 927 do Código Civil e tem que ser bem caracterizada pela Doutrina e Jurisprudência para que não se extrapole sua

22 Na verdade, a teoria subjetiva ou teoria com fundamento na culpa podc ainda admitir na sua evoluçào os temas da presunção de culpa relativa (juris tantum) e presunção absoluta de culpa (juris et de jure) que, na realidade, é presunção irrefragável de responsabilidade. somente admitindo como excludentes o caso fortuito, a força maior. a culpa exclusiva da vitima e o fato de terceiro externo ao acontecimento. 
aplicação, o que geraria, em muitos casos, graves injustiças. Esse dispositivo será melhor estudado em item posterior.

Porém, antes de mais nada, é preciso deixar claro que responsabilidade objetiva não é sinônimo de teoria do risco. ${ }^{23} \mathrm{~A}$ responsabilidade objetiva pode ter outros fundamentos que não o risco criado por pessoas ou empresas no meio social. Ou seja, a responsabilidade é objetiva porque, assim, a lei determinou. O ofensor vai responder segundo a averiguação objetiva de sua conduta, que se subsume à fattispecie descrita na lei.

Assim, são responsáveis objetivamente, ainda que não haja culpa de sua parte, os pais pelos filhos menores que estiverem sob sua autoridade e companhia; o tutor e o curador pelos próprios pupilos e curatelados, que se acharem nas mesmas condições dos pais; o empregador ou comitente por seus empregados, serviçais e prepostos, no exercício do trabalho ou em razão dele (conforme arts. 932 e 933 do Código Civil).

Trata-se da responsabilidade civil pelo fato de terceiros, que não se fundamenta no risco criado socialmente, mas tem como regra de fundo a presunção de responsabilidade dessas pessoas porque não agiram com diligência, não criaram bem seus filhos, não vigiaram seus empregados e assim por diante. Não é o risco e sim a autoridade e o poder de controle sobre esses terceiros. Portanto, basta a situação jurídica descrita nos arts. 932 e 933 existir para que nasça a obrigação de indenizar. Ou seja, a responsabilidade pelo fato de terceiros é objetiva; a obrigação de indenizar surge depois do dano.

O mesmo se diga da responsabilidade objetiva do dono ou detentor do animal que ressarcirá o dano por este causado somente pelo fato de ser seu dono ou detentor. Sua responsabilidade nasce daí, e somente não-pagará pelos danos causados por seu animal se provar a culpa da vítima ou força maior (art. 936 do Código Civil).

Também, dentro desse mesmo capítulo, há a responsabilidade civil pelo fato das coisas inanimadas. Responde o dono de edifício ou construção pelos danos que resultarem de sua ruína. Porém, há uma ressalva que enfraquece essa responsabilidade apesar de objetiva, qual seja, o dono do edifício pode provar em contrário alegando que a necessidade de reparos não era manifesta. Ora, se estivéssemos diante da teoria do risco, responderia sempre, só quebrando o nexo causal o fortuito, a força maior, a culpa da vítima ou de terceiro.

2 Agostinho Alvim, in "Exposição de motivos complementar do relator" (25-3-1973), mostra que havia proposto no projeto primitivo, texto correspondente ao parágrafo único do art. 927 atual, a redaçào "independentemente de culpa no lugar de risco", pois risco, segundo ele. "não coincide inteiramente com a responsabilidade que independe de culpa" 
De outro lado, a responsabilidade objetiva em sentido estrito, sem excludentes específicos ou ressalvas, é aquela pelos effusis et dejectis, ou seja, responde aquele que habitar prédio ou parte dele pelo dano proveniente das coisas que dele caírem ou forem lançadas em lugar indevido.

Finalmente, é preciso não esquecer que a responsabilidade pelo abuso do direito (art. 187 do Código Civil) é de aferição objetiva, bastando que a conduta do agente exceda manifestamente os limites impostos pelo fim econômico e social do direito, pela boa-fé ou pelos bons costumes. Não se leva em consideração a intenção do agente, como falado no item anterior. ${ }^{24}$

Portanto, a responsabilidade objetiva nem sempre significa risco criado pela atividade seja ela perigosa ou não.

A teoria do risco é um dos tipos de responsabilidade objetiva que, além de contar com uma série de leis especiais que a prevêem hoje, vem definida em cláusula geral que se aplica a todos casos que se enquadrem no seu tipo legal e que não façam parte de lei especial (art. 927, § único do Código Civil). Sobre essa cláusula geral trataremos nos itens seguintes.

Por outro lado, o Projeto de Código Civil de 1975, que durante quase 30 anos foi debatido e emendado, finalmente tornando-se o Código Civil, de 2002, teve uma influência enorme, enquanto Projeto, no Direito brasileiro anterior ao novo Código, pois, como à época era o mais moderno esboço de legislação, porquanto mais adaptado à realidade das mudanças no mundo contemporâneo, teve imediatamente suas normas sobre a pessoa, direitos da personalidade, dano moral, função social da propriedade, família, etc, inseridas na Constituição Federal de 1988 e, assim, veio a determinar regras de conduta no sistema privatístico que, mesmo com a promulgação do novo Estatuto Civil, continua sendo nossa Lei Fundamental, a norma integradora de todo esse sistema.

A Constituição Federal, de 1988, prevê a defesa do consumidor como um dos direitos e garantias fundamentais (CF, art. $5^{\circ}, \mathrm{XXXII)}$. Dessa forma, é promulgado o Código de Defesa do Consumidor em 1990 (Lei n. 8.078/1990, com entrada em vigor em 1991) que traz uma revolução em termos de proteção aos consumidores, principalmente no que diz respeito à responsabilidade civil dos fornecedores e às abusividades contratuais.

$\mathrm{Na}$ matéria que nos interessa, podemos afirmar que, também inspirado pelo Projeto de Código Civil de 1975 e acompanhando as tendências da moderna responsabilidade civil em todo Direito Contemporânco, veio a legislação consumerista

24 Enunciado 37, da Jomada I. do STJ: "A responsabilidade civil decorrente do abuso do direito independe de. culpa e fundamenta-se somente no critério objetivo-finalistico" 
endurecer com o causador do dano. Adota-se nele a teoria objetiva do risco da atividade, na qual o fornecedor vai sempre responder, somente se eximindo se tiver a seu favor algumas das excludentes específicas, que deverá provar: como a de que não colocou o produto no mercado ou que, embora haja colocado o produto no mercado, o defeito inexiste ou ainda a culpa exclusiva do consumidor ou de terceiro (art. $12, \S 3^{\circ} \mathrm{CDC}$ ). O mesmo se diga em relação aos prestadores de serviços, que sempre respondem, independentemente de culpa, e que para elidirem sua responsabilidade deverão provar que, tendo prestado o serviço, o defeito inexiste ou que houve culpa exclusiva do consumidor ou de terceiro (art. 14, $\S 3^{\circ}$ C.DC). Todavia, deixou para a teoria subjetiva a fundamentação da responsabilidade pessoal dos profissionais liberais, pois essa somente será apurada mediante verificação de culpa, ${ }^{25}$ mas sempre dentro dos princípios do Direito do Consumidor.

Em suma, todas essas considerações foram para mostrar que as regras sobre responsabilidade civil que estão no Código Civil, de 2002, foram influenciadas pela Constituição Federal (dano moral, por exemplo) e pelo Código de Defesa do Consumidor (risco da atividade), mas que, na verdade, tudo se origina no Projeto de 1975, tendo havido, portanto, um fluxo e refluxo legislativo que acabou preenchendo a lacuna criada pela morosidade na publicação da nova lei civil.

4.3. O significado de atividade de risco contido no $\S$ único do art. 927 do Código Civil de 2002

\subsubsection{Introdução}

Já vimos que o novo Código Civil adotou as duas principais teorias informadoras da responsabilidade civil e o fez por meio de cláusulas gerais; a primeira é a teoria subjetiva. que continua sendo o principal fundamento de nosso direito de danos. e se expressa pelos arts. 186 e 927 , caput: a segunda cláusula geral está no parágrafo único do mesmo art. 927 e determina o obrigação de reparar. independente de culpa, nos

Há, de outro lado. mesmo nesse caso. a possibilidade processual da inversão do ônus da prova, o que facilita a tarcfa probatória para a vilima. "Art. $6^{\circ}$ São direitos básicos do consumidor: (...) VIII a facilitação da defcsa de seus direitos, inclusive com a inversão do ônus da prova, a seu favor, no processo civil, quando, a critério do juiz, for verossímil a alegação ou quando for ele hipossuliciente, segundo as regras ordinárias de experiência" 
casos especificados em lei, ${ }^{26}$ ou quando a atividade normalmente desenvolvida pelo autor do dano implicar por sua natureza, risco para os direitos de outrem.

Portanto, continua sendo a culpa do agente o principal fundamento para a reparação do dano. A regra do parágrafo único do art. 927 somente será aplicada nos casos de atividades que ponham em perigo os direitos de outrem. A lei se refere a direitos e quer, com isso, englobar tanto os danos ao patrimônio, quanto os danos à pessoa, inclusive os danos morais.

\subsubsection{Ato, atividade e produto}

Sem dúvida nenhuma, para a interpretação correta do parágrafo único do art. 927 do Código Civil, é preciso, antes de mais nada, definir e diferenciar os três conceitos básicos citados neste item. ${ }^{27}$

Segundo W. Bulgarelli ${ }^{28}$ a noção de atividade no âmbito da Teoria Geral do Direito, não tivera até Tullio Ascarelli, relevo maior, ficara obscurecida pela importância dada à teoria dos negócios jurídicos. Essa insuficiência teórica foi também percebida por Vicenzo Pannuccio e a partir daí ambos começaram a estudá-la de maneira geral. ${ }^{29}$

A primeira tarefa dos juristas foi separar os conceitos de atividade e ato. Ascarelli, no estudo sobre a atividade na teoria de empresa, procura demonstrar a

26 C'onstituição Federal, art. $37, \S 6^{\circ}$ (Responsabilidade Civil do Estado) qui adota a teoria do risco administrativo: "As pessoas jurídicas de direito público e as de direito privado prestadoras de serviços públicos responderão pelos danos que seus agentes, nessa qualidade, causarem a terceiros, assegurado o direito de regresso contra o responsável nos casos de dolo ou culpa" Dec. n. 2.681/1912 (Responsabilidade Civil das Estradas de Ferro); arts. 81 a 88 da Lei n. 4.117/62 (Código Brasileiro de Telecomunicações); Dec. n. $61.867 / 1967$ (regulamenta seguro obrigatório do art. 20 do Dec. Lei $n$. 731/1966); Lei n. 6.453/1977 (Responsabilidade civil por danos nucleares); Dec. n. 79.437/1977 (promulga a Convenção Intemacional sobre Responsabilidade Civil em Danos por Poluição por Óleo); arts. 20 e 21 da Lei n. 8884/94 (Lei de Proteção à Concorrência); Lei n. 7.195/1984 (Responsabilidade Civil da Agência de Empregado); Lei n. 7.347/1985 (Açào Civil Pública de responsabilidade civil por danos ao meio ambiente, ao consumidor, a bens e direitos de valor artistico, estético, histórico, turistico e paisagístico); Lei n. 7565/1986 (Código Brasileiro de Aeronáutica); Lei n. 8.078/1990 (Código de Defesa do Consumidor); Dec. n. 911/1993 (promulga a Convenção de Viena sobre Responsabilidade Civil pur Danos Nucleares); art. 25 da Lei n. 9.966/2000 (Prevenção, controle e fiscalização de poluição por óleo em águas): Súmulas 28. 492 e 562 do Supremo Tribunal Federal: Súmulas ns. 37, 186 e 227 do Superior Tribunal de Justiça.

27 Já no Direito Romano tínhamos, de uma certa forma, esta diferenciação. C. Cannata, Sul problema della responsabilità nel dirillo privato romano, usa os termos artifex e ars, que podem ser adaptados a profissional e atividade. Dentro de uma determinada categoria profissional pode haver diferentes modelos de arlifices, conforme as várias especializaçōes. Apud MAFFEIS, Marta Rodrigues. Contribuição do estudo da responsabilidade civil do médico à luz do Direilo Romano. 2004. Tese (Doutorado) - Faculdade de Direito, Universidade de São Paulo, São Paulo.

28 BUlgarelli, Waldirio. A Teoria Juridica de Einpresa. 1984. Tese (Professor Titular) Faculdade de Direito da Universidade de São Paulo, São Paulo. p. 175.

29 ASCARELlI, Tullio. Corso di Diritto Commercials. 3. ed. Milão: 1962; PANNUCCIO. Vicenzo. Teoria Giuridica Dell'Impresa. Milão: 1974, apud W. Bulgarelli. 
separação entre ato e atividade, com acento na finalidade. "Atividade não significu ato, mas, uma série de atos coordenados entre si em relação à finalidade comum" io Portanto, a atividade é autônoma, não se confunde com os atos isolados que a compõem e também permanece estranha à causa desses atos. Como exemplo, temos o ato do motorista (dirigir) da empresa de ônibus que não se confunde com a atividade de transporte de pessoas e coisas. Em suma, a atividade tem na sua essência uma séria de atos coordenados em razão de um fim profissional e econômico, o que obrigatoriamente tem de ser feito com habitualidade, e não esporadicamente.

Do que falamos, podemos tirar uma primeira conclusão, qual seja, a expressão "atividade normalmente desenvolvida" que aparece no parágrafo único do art. 927 refere-se, na maioria dos casos, à atividade empresarial e, excepcionalmente, a série de atos que a pessoa física pratica com habitualidade pondo em risco a segurança alheia. Não podemos colocar no mesmo conceito uma atividade individual e isolada, como a de dirigir automóveis. Nesse caso, serão os atos do motorista, e a sua conduta diligente ounão, que estarão em julgamento.

Essa afirmação encontra apoio no Código de Defesa do Consumidor, pois o fornecedor é aquele que exerce uma atividade (art. $3^{\circ}$ do CDC) e o "serviço é qualquer atividade fornecida no mercado de consumo, mediante remuneração, inclusive os de natureza bancária, financeira, de crédito e securitária, salvo as decorrentes das relações de caráter trabalhista" (art. $3^{\circ}, \S 2^{\circ}, \mathrm{CDC}$ ). No sistema consumerista essa atividade (seqüência de atos coordenados a um fim lucrativo, com habitualidade) pode também ser exercida por uma pessoa física. Como exemplo, temos os prestadores de serviços individuais, como dentistas, médicos, encanadores, técnicos em computação, etc.

Finalmente, é preciso não confundir atividade ou mesmo ato, com produto, que é o resultado de uma atividade (resultado da produção). Essa diferença também é fundamental, pois a atividade pode não ser perigosa, não pôr em risco os direitos de outrem, mas o seu produto pode ser perigoso para a segurança ou a saúde de quem o consome. Como exemplo, temos o caso do tabaco. A fabricação de cigarros ou charutos é extremamente segura e não põe em risco nem os operários, nem as pessoas do meio social. Os cigarros, já está provado, podem ser nocivos ou perigosos à saúde do consumidor. Sobre a perfeita significação desses conceitos em Direito, temos acórdão emblemático do Tribunal de Roma, julgado em 04/04/1997, no qual se lê: "Non é configurabile una responsabilità per esercizio di attività pericolosa del produttore di sigarette, dal momento che l'ambito della norma di cui all'art. 2.050 c.c. è limitato ai danni ricollegabili ad attività che, nel loro svolgimento, creino situazioni di pericolo o

30 BULGARELLI, Waldirio. Op. cit., p. 185. 
rendano probabile il verificarsi di incidenti; nel caso di specie. invece, il danno deriva dal consumo di sigarette e non si può affermare che queste abbiano uma potenzialità lesiva riconducibile allo svolgimento dell'attività di cui costituiscono risultato (Trib. Roma 4.4.97, DaR, 1997, 750)" 31

O próprio Código Civil, de 2002, admite essa diferença ao cuidar da responsabilidade por fato do produto em outro dispositivo. Segundo o art. 931. "ressalvados outros casos previstos em lei especial, os empresários individuais e as empresas respondem independentemente de culpa pelos danos causados pelos produtos postos em circulação" Portanto, também adotou a teoria objetiva na esteira do Código de Defesa do Consumidor, para a responsabilidade pelo risco do produto.

Todavia, essa diferença vai ter importância não-só para o Direito Comercial, mas também para o Direito do Consumidor e agora para o Direito Civil. É impossível analisar a teoria da indenização sem que esses conceitos estejam bem definidos.

4.3.3. A atividade normalmente desenvolvida pelo autor do dano deve trazer, por sua natureza, risco para os direitos de outrem.

Estamos diante da teoria do risco criado pela atividade. Toda atividade que cria riscos cria também perigos?

Para Sergio Cavalieri Filho risco é perigo, risco é probabilidade de dano e conclui: "o dever que se contrapõe ao risco é a segurança" Portanto todo aquele que exerce atividade perigosa deve exercê-la com segurança. A lei não pune ninguém simplesmente por exercer atividade de risco, ainda que inerente, afirma. ${ }^{32}$

No parágrafo único do art. 927 o legislador quis se referir somente à atividade perigosa, ou seja, que por sua natureza implica em riscos para terceiros. A prática de atos que diuturnamente estão pondo em risco a saúde e a segurança da população é perigosa, pois intrinsecamente perigosa. Corno exemplo, temos os transportes (aéreo, marítimo e terrestre), as atividades em que se usa armas (seguranças particulares ou policiais - Responsabilidade do Estado, art. 37. $\S 6^{\circ}$. da CF), trabalhos de consertos em estradas, obras de concessionárias do serviço público (hoje regidos pela teoria do risco administrativo do art. $37, \S 6^{\circ}$ da Constituição Federal), atividades esportivas (corridas de automóveis, asa delta, esqui na neve ou aquático, equitação),

31 In: "La Responsabilità Civile da attività pericolose". Paolo Recano, pp. 223, Padova (Itália): Ed. Cedam, 2001.

32 CAVALIERI FILHO, Sergio. Responsabilidade Civil no Novo Código Ciril. Revista da EMERJ, v. 6, n. 24, p. 30 e segs. 
hombas de gasolina, emissões radioativas (Lei Responsabilidade Civil por atividade nuclear de 1977), fábrica de fogos, pirotecnia, venda de gás engarrafado.

O Direito estrangeiro segue essa linha, pois foi o Código Civil italiano, no art. 2.050, que inspirou o parágrafo único do art. 927. Na sua primeira versão, no anteprojeto de 1972, havia, na verdade, uma presunção de culpa, podendo o autor do dano provar em contrário, demonstrando que adotara todos as medidas idôneas para evitar o dano. Гssa versão que se repete no Projeto n. 634, de 1975, de lavra do grande jurista Agostinho Alvim, continha a ressalva do Código Civil italiano, ou seja, ao mesmo tempo que o Direito Civil brasileiro adotava expressamente a teoria do risco, admitia que o autor do dano se exonerasse do dever de repará-lo se comprovasse que havia empregado medida preventiva tecnicamente adequada. Em outras palavras, adotava-se a teoria objetiva, na sua modalidade de risco da atividade perigosa, e, ao mesmo tempo, admitia-se a referida ressalva para elidir essa responsabilidade. Ficava, assim, enfraquecido o preceito. ${ }^{33}$ A Emenda n. 526, do Relator Especial Cleverson Teixeira, em 1983, suprimiu do parágrafo único do art. 963 do Projeto n. 634/1975 a expressão "salvo se comprovado o emprego de medidas preventivas tecnicamente adequadas" Assim abraçou o Projeto a teoria do risco criado pela atividade. Em seguida, o Parecer do deputado Brígido Tinoco (1983), acolhendo a emenda, pediu que fosse suprimida a palavra "grande". antes do risco. Justificava que, assim. suprimia-se o arbítrio ou apreciação subjetivas. Dỉia que não importa o tamanho do risco; o que importa é sua existência. Na redação atual também não aparece a conjunção "todavia" que abria o parágrafo único do art. 927.

Nessa mesma linha, mas com ênfase no perigo, temos o Código Civil mexicano, art. 1.913; Código Civil boliviano, art. 998; Código Civil peruano, art. 1.970: Código Civil paraguaio, art. 1.846; e Projeto de Código Civil argentino de 1998, art. 1.665. No mesmo teor do Código Civil italiano, temos o Código Civil português que no art. 493, n. 2, dispõe que "quem causar danos a outrem no exercício de uma atividade, perigosa por sua própria natureza ou pela natureza dos meios utilizados, é obrigado a repará-los, exceto se mostrar que empregou todas as providências exigidas pelas circunstâncias com o fïm de os prevenir"

Outro problema conexo di $z$ respeito às atividades que não são perigosas. mas que se tornam perigosas pela conduta do agente. Por exemplo, um cozinheiro que não sabe distinguir a comida sadia da estragada e põe em risco a saúde ou vida das

33 Art. 963. § único, Projeto/75: "Todavia. haverá obrigação de reparar o dano, independentemente de culpa, nos casos especificados em lei, ou quando a atividade normalmente desenvolvida pelo autor do dano implicar, por sua natureza. grande risco para os direitos de outrem, salvo se comprovado o emprego de medidas preventivas tecnicamentc adequadas" 
pessoas que se alimentaram. Nesse caso, a responsabilidade vai ser fundamentada no ato ilícito (teoria subjetiva), porém se se tratava de cozinheiro de restaurante, a responsabilidade vai ser fundamentada no risco da atividade do Código de Defesa do Consumidor. ${ }^{34}$

Por outro lado, ainda temos que lembrar que o Código de Defesa do Consumidor adotou a teoria do risco da atividade e sempre o fornecedor vai responder pelos danos ao consumidor, danos esses à saúde, integridade física e também ao patrimônio. Na verdade, o teor do parágrafo único do art. 927 é praticamente o mesmo dos arts. 12 e 14 do Código de Defesa do Consumidor. Para o sistema consumerista. havendo dano (vindo ou-não de atividade perigosa) terá lugar a indenização, a menos que essa responsabilidade seja elidida por alguma das excludentes.

É preciso que a Doutrina e a Jurisprudência dêem os limites para a responsabilidade pela atividade perigosa (nem ato, nem produto), pois tudo na vida apresenta risco e perigo e se começarmos a interpretar todas as atividades como perigosas acabaremos por colocar também os indivíduos respondendo pela teoria do risco, como, por exemplo, o dano provocado por um ciclista ou até de uma dona de casa empurrando o carrinho de supermercado...

Por outro lado, a teoria do risco trata da responsabilidade pela atividade lícita. Além disso, não basta o risco criado para gerar indenização, é necessário que tenha ocorrido o evento danoso. Ninguém responde porque criou risco, em princípio.

Por fim, a responsabilidade pelo risco da atividade no Brasil admite excludentes como força maior, culpa exclusiva da vitima ou fato de terceiro. É o que a doutrina chama de teoria do risco mitigada.

Penso que a interpretação extensiva do parágrafo único do art. 927 pode causar grandes prejuízos às empresas, além de ferir os princípios e valores constitucionais que fundamentam a ordem econômica (art. 170 da Constituição Federal), ${ }^{35}$ como a livre iniciativa, a livre concorrência e a função social da propriedade que se reflete na função social dos contratos. Não podemos nos esquecer que são fundamentos da República os valores sociais do trabalho e da livre iniciativa.

34 No mesmo sentido, VISIN [INI, Giovanna. Trattato breve della responsabilitá civile. 2. ed. Padova: Fd. Cedam, 1999. p. 734-744.

35 Art. 170 da Constituição Federal brasileira: "A urdem econômica, fundada na valorização do trabahho humano e na livre iniciativa. tem por fim assegurar a todos existência digna, conforme os ditames da justiça social, observados os seguintes principios: I soberania nacional: II propriedade privada; III função social da propriedade; IV livre concorrência; $V$ defesa do consumidor; VI defesa do meio ambiente; VII redução das desigualdades regionais e sociais; VIII busca do pleno emprego; IX tratamento favorecido para as empresas de pequeno porte constituidas sob as leis brasileiras e que tenham sua sede e administração no Pais. Parágrafo único. $\dot{E}$ assegurado a todos os livrc exercicio de qualquer atividade econômica. independentemente de autorização de órgãos públicos. salvo nos casos previstos em lei". 
5. Modificações no capítulo da indenização. Redução da indenização por eqüidade, conforme o grau de culpa. A culpa concorrente. O pagamento de indenização pelo incapaz

\subsection{Graus de culpa}

Abre o capítulo da indenização regra fundamental nessa matéria, isto é, a indenização mede-se pela extensão do dano (art. 944, caput). Em Direito Civil, em princípio, se não há dano, não há lugar para indenização, diferentemente do Direito Penal no qual a simples tentativa de crime leva à sanção criminal.

Porém. a regra do caput do art. 944 sofre uma ressalva que é, talvez, uma das mais polêmicas e importantes inovações dentro do Código Civil. Dessa forma, reza seu parágrafo único que "se houver excessiva desproporção entre a gravidade da culpa e o dano, poderá o juiz reduzir, eqüitativamente, a indenização"

De fato, a regra do § único do art. 944 mexeu com uma tradição de séculos. pois in Lex Aquilia et levissima culpa venit. Assim. sempre o tamanho do dano, e não da culpa. que deu a medida da indenização.

A regra revoluciona a teoria da indenização, pois em nome da justiça, permite ao juiz. usando da eqüidade, reduzir o quantum ressarcitório caso a culpa seja desproporcional em relação ao dano.

Dessa forma, voltamos aos graus de culpa, que, conforme a concepção tradicional, é dividida em culpa grave, leve e levíssima. ${ }^{36}$ Segundo Silvio Rodrigues ${ }^{37}$ a culpa grave é aquela decorrente da imprudência ou negligência grosseira, como a do motorista que dirige sem estar habilitado, ou a daquele que, em excesso de velocidade,

36 Marta R. Maffeis mostra $\mathrm{cm}$ sua tese de Doutorado que desde o Direito Romano o fato da culpa se diferenciar do dolo, levou os juristas a fazerem a classificação dos graus de culpa, pois a falta de cuidado poderia ser maior ou menor. A culpa lata referia-se a negligência grosseira, no qual o agente causador do dano age sem a minima cautela, não prevendo o que todos prevêem. "Seus efeitos, portanto, equiparam-se ao dolo", fundamentando cm L'lpiano I reg. D. 50, 16, 213, 2: "Lata culpa est nimia negligentia, id est non intellegere quod omnes intellegunt" A culpa levis é a culpa-negligência e a culpa levissima, corresponde ao grau de diligência exigido pela "Lex Aquilia" que responsabiliza pelo dano até aquele que teve diligència acima do normal - "In lege Aquilia el levissima culpa venit" (Ulp. Fragmento 42 ad Sab., D. 9, 2, 44). Sobre a utilização dos termos "culpa lata" e "culpa levis", há três teses, como demonstra Marta Maffeis. Para a primeira esses termos surgiram apenas na época pós-clássica; para a segunda já existiam raizes de tal distinção no direito clássico, mas apenas no direito pós-clássico é que se tornaram categorias autônomas. E. Betti (Teoria Generale delle obligazioni) acredita que apenas no direito comum. e não no direito pós-clássico, é que os graus de culpa surgem com nítida delimitação dogmática. A terceira use defende que a classificação em "culpa lata" e "culpa levis" jả existia no direito clássico. nesse sentido conforme G. Maccormack in "Culpa", 1972 (Cf. MAFFEIS. Marta R. Contribuição ao estudo da responsabilidade civil do médico à luz do Direito Romano, 2004. Tese (Doutorado) - Faculdade de Dircito, I niversidade de São Paulo. São Paulo. p. 92 e 93.

19 RODRIGl IES, Silvio. Direito Civil responsabilidade civil. 19. ed. São Paulo: Saraiva, 2002. p. 148 e segs. 
atravessa um sinal de trânsito fechado. Para o querido mestre, seguindo a tradição que vem do Direito Romano, a culpa grave ao dolo se equipara. Poderíamos lembrar que quem age com culpa grave, está agindo com a previsibilidade de causar dano, é o que em Direito Penal se chama de dolo eventual; a pessoa assume o risco de prejudicar outrem, como no caso de fazer corrida de automóvel nos centros urbanos (o chamado "racha") e que, geralmente, causa ferimentos e mortes à população.

A culpa leve é aquela que "o bom pai de família" pode cometer. É a culpa da pessoa normal. Faltou atenção e diligência. A culpa levíssima é, segundo Silvio Rodrigues, ${ }^{38}$ aquela da qual mesmo um homem de extrema cautela não poderia deixar de escapar. Repita-se que na responsabilidade aquiliana mesmo que a culpa seja levíssima leva o agente causador do dano a indenizar a vítima na medida desse dano (In Lex Aquilia et levíssima culpa venit).

A regra do $\S$ único do art. 944 tem sido foco de divergências doutrinárias. Muitos juristas vêem nessa regra uma injustiça com a vítima, sobre a qual cairia a diferença da indenização não-paga, pois a indenização tem que ser a mais completa possível, tendo como finalidade tornar a vítima indene, levando-a ao statu quo ante.

Silvio Rodrigues ${ }^{39}$ aplaude a inovação porque a medida da indenização somente pelo dano às vezes pode ser injusta, pois não raro de culpa levíssima resulta dano desmedido à vítima. É o caso de pessoa que distraidamente deixa cair um objeto de um prédio e que acaba matando um chefe de família com cinco filhos. Deverá pagar soma altíssima como pensão, até os filhos crescerem. Portanto, permite o novo dispositivo que o juiz, julgando por eqüidade, dose a indenização se achar que assim é mais justo, de acordo com o grau de culpa, depois de examinadas todas as circunstâncias do caso concreto. Pode ser que o juiz não abaixe a indenização apesar da desproporção entre dano e culpa, pois, dentro do seu livre convencimento, achou mais justo assim.

O Código Civil português, de 1967, contém artigo no mesmo sentido. O art. 494 trata da limitação da indenização no caso de mera culpa. "Quando a responsabilidade se fundar em mera culpa, poderá a indenização ser fixada, eqüitativamente, em montante inferior ao que corresponderia aos danos causados, desde que o grau de culpabilidade do agente, a situação econômica deste e do lesado e as demais circunstâncias do caso justifiquem"

Portanto, adota também o Direito português o julgamento por eqüidade e a lei já determina uma série de circunstâncias que dão apoio ao juiz para justificar a maior ou menor redução da indenização, diferente do Código Civil brasileiro. Como afirma

38 Id. Ibid.

39 RODRIciltES. Silvio. Direito Civil - responsabilidade civil. 19. ed. São Paulo: Saraiva, 2002. 
Pires de Lima e Antunes Varela ${ }^{40}$ quanto à culpabilidade do agente, interessará avcriguar se ele agiu com culpa lata, leve ou levíssima. Pela situação econômica dos interessados, vai o juiz averiguar a repercussão qui terá o quuntum indenizatório sobre a situação patrimonial da vitima e do autor do ilícito.

O Código Civil italiano de 1942, no art. 2.056, que trata da valoração dos danos, remete aos arts. 1.223, 1.226 e 1.227 quanto ao ressarcimento devido ao danificado. Por sua vez, o art. 1226 contém cláusula geral sobre a valoração eqüitativa do dano, ou seja. o juiz vai julgar por eqüidade quando o dano não pode ser provado no seu quantum preciso, é assim "liquidato dal giudice con volutazione eqüitativa" Portanto, o juiz vai julgar por arbitramento, usando do critério da eqüidade. Isso se aplica a todos os casos.

Em suma, apesar da polêmica em torno da nova regra que prevê o julgamento por eqüidade, tal solução deve ser aplaudida, pois em muitos casos será o único jeito de chegar-se à justiça.

\subsection{Culpa concorrente}

$\mathrm{Na}$ mesma esteira do dispositivo anterior, temos o art. 945 que determina que "se a vítima tiver concorrido culposamente para o evento danoso, a sua indenização será fixada tendo-se em conta a gravidade de sua culpa em confronto com a do autor do dano"

Portanto, a indenização no caso de concorrência de culpas será medida não pelo dano de cada um, mas pela culpa, ou melhor pela gravidade da culpa. do autor e da vítima do dano. Neste caso, também deverá ser levado em consideração o critério dos graus de culpa. A regra foi acolhida, na Parte Especial, no contrato de transporte, que hoje integra o Código Civil. O art. 738, § único, do Código Civil, permite a redução da indenização por eqüidade, no caso de culpa concorrente ${ }^{4 l}$ da vítima com o transportador.

40 LiMA, F. A. Pires de; VARELA, J. M. Antunes. Código civil anorado. Portugal: Coimbra Editora Ltda., 1967. v. 1. p. 339.

4) "Responsabilidade Civil. Ferrovia. Passagem clandestina. Concorrência de culpa. A companhia ferroviária iem o dever de cuidado e conservação de ccrcas e muros que ergue ao longo das linhas férreas, não podendo permitir o uso de passagem clandestina pelos moradores próximos da estrada. A existência de passarela, que poderia ter sido utilizada para a travessia. caracteriza a culpa concorrente da vitima" (STJ, RESP 480357/SP, relator ministro Ruy Rosado de Aguiar, Quarta Turma, julgado em 18/02/2003. publicado em 15/09/2003. Grifos nossos).

"Civil. Ação de indenização. Saque de importância de correntista por tercciro, com uso de cartão magnético. Falta de precaução do titular, aliada à negligência do banco $\mathrm{cm}$ autorizar a transferência de valores da conta de poupança para a conta corrente, sem as cautelas de praxe. Concorrência de culpas. Ressarcimunto reduzido à metude. I. Siruç̧ão em que se identifica. com base no voto médio, a concorrência dé culpas da autora e do banco, a primeira por entregar o cartão e informar senha a pessoa amiga, que permitiu o acesso a terceiro sobre os dados sigilosos, e do rén por atuar negligentemente 
Bem interessante é o que o Código Civil português dispõe na $1^{a}$ parte do art. 570: "quando um facto culposo do lesado tiver concorrido para produção ou agravamento dos danos, cabe ao tribunal determinar, com base nas gravidades das culpas de ambas as partes e nas conseqüências que delas resultaram, se a indenização deve ser totalmente concedida, reduzida_ou mesmo excluída"

Mario Pogliani, ${ }^{42}$ comentando o art. 1.227 do Código Civil italiano, diz que o dispositivo citado trata especificamente da hipótese de limitação da responsabilidade por fato culposo do credor. Mas afirma que, apesar de tal dispositivo dizer respeito a obrigação obrigações de natureza negocial, encontra aplicação também no campo extracontratual. Em seguida, mostra que nos encontramos na presença de um aspecto particular do princípio da causalidade, pelo qual, de modo totalmente excepcional, vem colocada a derrogação da regra geral da irrelevância das concausas. Dessa forma, a responsabilidade do autor do dano acaba por encontrar uma limitação pela culpa concorrente da vítima. E a responsabilidade do autor do dano deve ser reduzida no tanto que corresponde à participação culposa da vítima na produção do evento danoso.

E no Direito brasileiro atual, é admitida a culpa concorrente da vítima como causa de redução da indenização quando se tratar da teoria do risco da atividade ou mesmo em caso de responsabilidade objetiva prevista cm lei?

Apesar do Fnunciado n. 46 das Jornadas de Direito Civil do STJ entender que "a possibilidade de redução do montante da indenização em face do grau de culpa do agente, estabelecida no parágrafo único do art. 944 do novo Código Civil, deve ser interpretada restritivamente, por representar uma exceção ao princípio da reparação integral do dano, não se aplicando às hipóteses de responsabilidade objetiva" ¿̇ perfeitamente possível usar-se o critério do art. 945 mesmo no caso de responsabilidade fundada no risco, pois no contrato de transporte (risco da atividade) está prevista a eqüitativa redução da indenização na medida em que a vítima (passageiro) houver

quando da solicitação, pelo fraudador, via telefónica, da transferência de valores da conta de poupança para a corrente, o que viabilizou a retirada subseqüente. II. Recurso especial conhecido em parte $\mathrm{e}$ parcialmente provido, para condenar o réu a ressarcir à autora metade dos danos apurados" (STJ, RESP 235385/SP, relator ministro Barros Monteiro, Quarta Turma, julgado em 11/12/2001, publicado em 01/07/2004. Grifos nossos).

"Civil e processual. Ação de indenização. Acórdão. Nulidade não-configurada. Colisão de motocicleta com ônibus. Vitima fatal. Concorrência de culpas reconhecida pelo tribunal estadual. Pensão fixada pela metade. Não se configura a nulidade do acórdão estadual se as questões suscitadas pela parte uu foram por ele enfrentadas, ou eram destituidas de fundamento. Reconhecida pclo Tribunal a quo a concorrência de culpas. cabivel a redução da condenação em igual proporção sobre a pensão a que foi condenada a ré. Recurso especial conhecido em parte e provido" (STJ, RESP 295622/RJ, relator ministro Aldir Passarinho Júnior, Quarta Turma, julgado em 12/03/2002, publicado em 20/05/2002).

^POGLIANI. Mario. Responsabilità e rissarcimento da illeciı civile. Milão: Ed. Giuffrè. 1909. 
concorrido para o dano (Cf. parágrafo único 738 CC/02). A regra do art. 945 somente vem mexer com o cálculo indenizatório e não com o fundamento da responsabilidade.

\subsection{O incapaz pode responder pelos prejuizos que causar}

Por muito tempo, debateu-se na Doutrina se o incapaz (arts. $3^{\circ}$ e $4^{\circ}$ do Código Civil, de 2002) ${ }^{43}$ rico ou com boa situação econômica devia responder com seu patrimônio pessoalmente caso as pessoas responsáveis por ele não dispusessem de meios suficientes. Em outras palavras, é o caso, por exemplo, do louco rico ou do menor que tem substancial patrimônio, pois recebeu doações dos avós e se tomou mais rico que seus pais, que não dispõem de meios para pagar indenizações vultosas pelos danos cometidos pelo incapaz.

Isso sempre preocupou a Doutrina, pois, como não tínhamos regra, e se a responsabilidade não pudesse ser atribuída à pessoa encarregada da vigilância do incapaz, a vítima ficava irressarcida, "da mesma maneira que ocorreria se o seu infortúnio derivasse do caso fortuito ou de força maior" 44

O novo Código Civil veio, inovando, e com fundamento na eqüidade, promulgar norma que corrige essa injustiça, sempre dentro dos requisitos da lei. Ou seja, o incapaz (amental ou menor) somente responderá e subsidiariamente, se as pessoas por eles responsáveis (pais, tutor, curador) não tiverem obrigação de fazê-lo ou não dispuserem de meios suficientes.

A lei deixa claro que essa indenização deverá ser eqüitativa, isto é, dentro dos parâmetros da justiça do caso concreto, e não terá lugar se privar o incapaz ou as pessoas que dele dependem do necessário (à sobrevivência).

Desse modo, tal norma veio proteger não-só as vítimas. mas principalmente os curadores e tutores que, além de exercer um munus de difícil desempenho, ainda devem pagar com seus bens pessoais, caso fique provado que os prejuizos foram causados quando o incapaz estava sob sua autoridade e companhia. E, hoje, essa responsabilidade é objetiva, pois segundo o art. 933, tais pessoas responderão, ainda que não haja culpa de sua parte, pois a responsabilidade por fato de terceiros, art.

43 "Art. $3^{\circ}$ São absolutamente incapazes de exercer pessoalmente os atos da vida civil: 1 - os menores de dezesseis anos; II - os que, por enfermidade ou deficiência mental, não tiverem o necessário discemimento para a prática desses atos: III os que, mesmo por causa transitória, não puderem exprimir sua vontade" "Art. $4^{\circ}$ São incapazes, relativamente a certos atos, ou à maneira de os exercer: I os maiores de dezesseis e menores de dezoito anos: Il os ébrios habiluais, os viciados em tóxicos, e os que, por deficiência mental, tenham o discernimento reduzido; III - os excepcionais, sem desenvolvimento mental completo; IV - os pródigos. Parágrafo único. A capacidade dos indios será regulada por legislação especial"

4 RODRIGUES, Silvio. Direito ('ivil - responsabilidade civil. 19. ed. São Paulu: Saraiva. 2002. v. 4. p. 25 
932 (pais pelos filhos menores, tutor e curador pelos pupilos e curatelados, empregador pelos empregados serviçais ou prepostos) é, no Código Civil, de 2002, informada pela teoria objetiva. ${ }^{45}$

Em suma, com a norma do art. 928, desvincula a noção de culpa da de imputabilidade, porquanto não precisa o agente causador do dano ter discernimento sobre as condutas lícitas ou ilícitas, basta que haja o dano e o nexo causal entre o prejuízo sofrido pela vítima e o ato do incapaz (menor ou louco). Poderão os inimputáveis responder pelos prejuízos causados desde que sejam preenchidos os requisitos da norma em tela, mais seu parágrafo único. O juiz será a peça chave na interpretação e aplicação da responsabilidade patrimonial do incapaz, sempre arbitrando uma indenização eqüitativa, que não prejudique nem o autor do dano, nem as pessoas que dele dependem, porquanto há muitas pessoas privadas de discernimento que "sustentam" sua família com seu patrimônio e suas rendas.

Essa regra foi inspirada no art. 2.047 do Código Civil italiano e no art. 489 do Código Civil português. O Código Civil italiano prevề, no art. 2.047, o dano causado pelo incapaz, e que no n. 1 contém presunção de culpa que milita contra aquele que é responsável pela vigilância do incapaz, admitindo, portanto, prova em contrário. Diferentemente do novo art. 932 do Código Civil brasilciro, combinado com art. 933, que prevê responsabilidade objetiva por fato de terceiro para as pessoas encarregadas de cuidarem e vigiarem os privados de discernimento. O art. 932, incisos I e II, admite como excludente prova, a ser feita pelos responsáveis pelo incapaz, de que esses não estavam em sua companhia ou-não estavam, sob sua autoridade no momento do evento danoso. Como exemplo, temos o caso da criança que no dia que cometeu o dano estava com o pai passando as férias, tendo, portanto, o genitor a sua guarda. ${ }^{46}$

Há antinomia entre essa regra e o art. 942, no seu parágrafo único, que determina que são solidariamente responsáveis com o autor, os co-autores e as pessoas designadas no art. 932. Como conciliar esses dois dispositivos? Acho que o art. 928 é caso especial de incapaz com mais posses que a pessoa que the tem a vigilância $\mathrm{e}$ somente nesse caso e se não privar o incapaz ou as pessoas que dele dependem do nucessário para sobreviver é que não se aplicará a solidariedade e o incapaz responderá

4. A súmula 341 do STF ("É presumida a culpa do patrão ou comitente pelo ato culposo do empregado ou preposto") está revogada por incompatibilidade com o novo sistema que adota para esse caso a responsabilidade objetiva.

s6 Todavia, o n. 2 do mesmo art. 2.047 do Código Civil italiano prevê expressamente que, no caso da vítima (danneggiato) não poder obter o ressarcimento daquele que é responsável pela guarda du incapaz, o jui $\iota_{\text {, }}$ consideradas as condições econômicas das partes, possa condenar o autor do dano a uma indenização eqüitativa (un'equa indennità). 
com seu patrimônio. Portanto, a responsabilidade econômica do incapaz por seus danos é subsidiária, dentro dos termos da lei.

Por sua vez, o Código Civil português de 1967, no art. 489, trata da indenização por pessoa inimputável: "1. Se o acto do causador dos danos tiver sido praticado por pessoa não imputável, pode esta, por motivo de equidade, ser condenada a repará-los, total ou parcialmente, desde que não seja possível obter a devida reparação das pessoas a quem incumbe sua vigilância. 2. A indenização será, todavia, calculada por forma a não privar a pessoa do inimputável dos alimentos necessários, conforme o seu estado ou condição, nem dos meios indispensáveis para cumprir os seus deveres legais de alimentos"

Como vemos, o novo Código Civil seguiu o Código Civil português de perto, considerando a responsabilidade pelos prejuízos causados pelo incapaz de discernimento, subsidiária e não-principal, mesmo assim deixando nas mãos do juiz a correta decisão, sempre fundamentada na eqüidade. Pires de Lima e Antunes Varela acham que o inimputável que seja condenado a reparar o dano fica tendo direito de regresso contra quem não cumpriu o dever de vigilância. ${ }^{47} \mathrm{O}$ dever de vigilância está no art. 491 do mesmo Código.

Também admitem a responsabilidade dos amentais o art. 829 do Código Civil alemão (BGB) e o art. 54 do Código Suíço das Obrigações.

6. A superposição de normas da responsabilidade civil no Código Civil e no Código de Defesa do Consumidor

\subsection{Noções gerais}

O grande problema que surge é a possivel superposição de normas, de um e de outro sistema, quando os institutos que estão no Código Civil, também estão previstos no Código de Defesa do Consumidor, estatuto por excelência protetivo.

$\mathrm{Na}$ verdade, o Código Civil é o principal ordenamento do sistema de Direito Privado brasileiro que se complementa com uma série de leis extravagantes, algumas constituindo microssistemas, e, dentre as quais, destacam-se o Código de Defesa do Consumidor (Lei n. 8.078 de 11/09/1990), a Lei das Locações (Lei n. 8.245 de 18/10/1991), o Estatuto da Criança e do Adolescente (Lei n. 8.069 de 13/07/1990), o Estatuto do Idoso (Lei n. 10.741 de 01/10/2003). Esse sistema se alimenta e se retroalimenta num ir e vir das normas, que poderíamos chamar, como faz Cláudia Lima

57 LIMA. Ficmando Andrade Pires de; VARELA. João Matos Antunes. Código civil anorado: comentários ao ant. $489^{\circ}$. Portugal: Coimbra Editora Ltda., 1967. v. I, p. 334. 
Marques, ${ }^{4 \varnothing}$ fundamentada em Erik Jayme, de "diálogo de fontes" no qual a norma mais apropriada ao caso ou mais protetiva do mais fraco, é a que vai ser aplicada para que se chegue ao julgamento justo.

O microssistema que mais poderia entrar em conflito com o Código Civil é, sem dúvida, o Código de Defesa do Consumidor, pois dispõe de matérias que também são previstas no Código Civil, como os contratos e a responsabilidade civil. Porém, a situação praticamente se repete, porque quando da promulgação do Código de Defesa do Consumidor, a preocupação de conflito poderia ter sido a mesma. Mas, na época, não foi o que aconteceu, porquanto o destaque do Código de Defesa do ('onsumidor para as relações negociais de consumo ficou claro e foi assim que sempre foi aplicado.

No caso da responsabilidade civil, o Código de Defesa do Consumidor tem como fundamento a teoria objetiva do risco da atividade, com exceção dos profissionais liberais cuja responsabilidade pessoal será apurada mediante a verificação de culpa (art. 14, $\S 4^{\circ} \mathrm{CDC}$ ), sem sair, porém, das regras do sistema consumerista, como já mencionado.

O Código Civil, apesar de continuar tendo como principal doutrina informadora a teoria subjetiva ou da culpa, "objetivou-se" de forma ampla, como vimos. Sem dúvida, recebeu a influência do seu microssistema consumerista, que por sua vez havia absorvido normas projetadas em 1975 e, principalmente, acompanhou a tendência contemporânea de, cada vez mais, englobar-se na teoria objetiva, em especial na teoria do risco, com número grande de hipóteses, sempre tendo em vista a proteção da coletividade, pois quem cria risco a outrem deve arcar com suas conseqüências ( $u b i$ emolumentum, ibi onus).

Como fica a incidência dos dois diplomas quando a fattispecie sobre as conseqüências do fato danoso (contratual ou extracontratual) está em ambos prevista?

Penso que não haverá dificuldade em resolver esse "conflito", nem nessa área, nem na área contratual (na qual vários contratos são coincidentes, como a prestação de serviços, a empreitada, a locação, etc).

Fazendo uma síntese da matéria podemos elencar as principais conclusões:

I. O Código de Defesa do Consumidor é lei principiológica, que fixa diretrizes que devem ser seguidas pelas leis setorizadas. ${ }^{49}$ A lei prevê a reparação mais

48 Conforme MARQueS, Cláudia Lima. Contratos no Código de Defesa do Consumidor. 4. ed. São Paulo: Revista dos Tribunais, 2002.

19 Conforme NERY. Nelson. Código Civil Anotado e Legislação Extravagante. 2. ed. São Paulo: Revista dos Tribunais. 2003. p. 913; NERY. Nelson. Código de Defesa do Consumidor Comentado pelos Autores. 6. cd. Rio de Janeiro: Forense. 1999. p. 444. No mesmo sentido, também citado por Nelson Nery, SODRÉ. Marcelo Gomes. As leis principiologicas de defesa do consumidor na América Latina: origens, importância e principais disposições, 2000. 2 v. Dissentação (Mestrado) - Pontificıa Universidade Católica, São Paulo. 
perfeita e possível do consumidor, que seguindo de perto a Constituição Federal de 1988 , inclusive, manda indenizar o dano moral. Como lembra o mesmo Nelson Nery, "as indenizações limitadas ou tarifadas, previstas em leis reguladoras de setores das relações de consumo, não mais têm aplicação em face da norma principiológica geral ora comentada, que deve ser respeitada pela legislação especial que regula cada tipo de consumo per se" so

Por outro lado, em sendo relação de consumo, em princípio, a proteção do sistema especial vai ser aplicada e nesse caso, a norma especial se superpõe à geral, ou, lex specialis derrogat lex generalis.

Todavia. o novo Código Civil também abraçou a teoria objetiva na vertente da teoria do risco da atividade (atividade perigosa). Quando aplicar o Código Civil? Somente em relações que não sejam de consumo. O Código Civil é lei geral e no $\S$ único do art. 927 contém cláusula geral que regula a responsabilidade nas atividades perigosas. O Código Civil deverá ser aplicado na responsabilidade que se origina nas relações paritárias ou no caso especifico de atividade perigosa, que não tenha lei especial prevendo, como fábrica de jogos, bombas de gasolina, transportes em geral, mas sempre tendo em vista atividade empresarial habitual e não atos esparsos de pessoas físicas.

2. A avaliação do dano moral deve ser feita por arbitramento e fundada na eqüidade, como vimos. Esse critério se aplica indiferentemente aos dois sistemas.

3. A proibição de estipulação contratual de cláusula de não-indenizar (ou cláusula de irresponsabilidade) no Código de Defesa do Consumidor (art. 51), sistema por excelência protetivo, não existe no Código Civil, que trata dos contratos paritários.

Para o sistema consumerista não importa se a responsabilidade é contratual ou extracontratual; sendo caracterizado o vínculo como relação de consumo, sempre vai emergir a obrigação de reparar o dano, pois se trata de responsabilidade ex lege (e a lei, no caso, é de ordem pública). ${ }^{51}$

4. Da mesma forma, a distinção entre obrigações de meio e de resultado é relativa para o sistema consumerista, pois as obrigações de meio podem também levar o devedor a ter de provar a sua não-culpa, caso haja inversão do ônus da prova. no caso de verossimilhança da alegação ou hipossuficiência do consumidor (Código de Defesa do Consumidor, art. $6^{\circ}$ VIII). como é o caso das profissões liberais, apesar de responsabilizados pela teoria da culpa. ${ }^{52}$ Além disso, a responsabilidade fundamentada no risco da atividade é sempre obrigação de resultado.

Op. cit., p. 913.

Conforme LOPEZ, Teresa Ancona. Comentarios ao Código ( ivil. São Paulo: Saraiva, 2003. v. 7, p. 197. Id. Ibid. 
5. Sobre os prazos para o exercício da ação de reparação de danos, o raciocínio deve ser o mesmo. Na relação especifica de consumo, segue-se o Código de Defesa do Consumidor quanto ao prazo de prescrição, ou seja, prescreve em cinco anos a pretensão à reparação de danos causados por fato do produto ou do serviço, iniciandose a contagem desse prazo a partir do conhecimento do dano e sua autoria (conforme art. 25 do Código de Defesa do Consumidor).

Se se tratar de indenização de fato danoso que não tenha se originado em contrato de consumo, aplica-se o art. 206, $\S 3^{\circ}$, V, do Código Civil, de 2002. Nesse caso o prazo prescricional será de três anos a partir do dano. ${ }^{53}$

7 Finalmente, sobre as excludentes da responsabilidade civil também devemos ficar atentos para a lei especial. Assim, não vai responder o fornecedor de produtos e serviços que provar que não colocou o produto no mercado, ou, que tendo colocado o produto no mercado ou tendo prestado o serviço, o defeito inexiste, ou ainda se provar que o dano adveio de culpa exclusiva da vítima (consumidor) ou de terceiro. As excludentes genéricas - caso fortuito ou de força maior - também serão aplicadas. Todavia, sendo relação de consumo deverá o fortuito interno, que é ligado à atividade do fornecedor, ser absorvido por este; ou seja, o dano que se originou de caso fortuito relacionado a essa atividade não servirá de excludente a seu favor. É o caso. por exemplo, do freio do táxi falhar e vir a ferir o passageiro (consumidor). O taxista deverá responder pelo dano.

No sistema do novo Código Civil, além das excludentes clássicas (caso fortuito, força maior, culpa exclusiva da vítima e estado de necessidade), houve a previsão da culpa concorrente, como atenuando o dever de indenizar do autor do dano. Dispõe o art. 945 que "Se a vítima tiver concorrido culposamente para o evento danoso, a sua indenização será fixada tendo-se em conta a gravidade de sua culpa em confronto com a do autor do dano"

O Código de Defesa do Consumidor não coloca a culpa concorrente como atenuante da responsabilidade do fornecedor. Como resolver esse conflito de leis no caso do dano ter origem em instituto previsto nos dois sistemas?

Sobre isso falaremos no sub-item seguinte, usando como exemplo a responsabilidade civil no contrato de transporte, que pela primeira vez aparece no Código Civil brasileiro.

\footnotetext{
-3 Devemos ter em mente. nesta fase de inicio de eficácia do novo Código Civil, que o art. 2.028 de suas "Disposiçōes Finais e Transitórias", dispõe que "Serão os da lei anterior os prazos, quando reduzidos por este Código, e se, na data de sua entrada em vigor, já houver transcorrido mais de metade do tempo estabelecido na lei revogada"
} 
6.2. O caso particular da responsabilidade civil no contrato de transporte. Há antinomia entre os sistemas do Código Civil, de 2002, e do Código de Defesa do Consumidor?

\subsubsection{Noções gerais}

Antes da vigência do Código Civil, de 2002, a responsabilidade civil advinda desse contrato (excetuando o transporte aéreo e maritimo) era regulada principalmente pelo Dec. Lei n. 2.681, de 07/12/1912, algumas leis esparsas e também súmulas. ${ }^{54}$ Não havia princípios norteadores. O novo Código Civil veio suprir essa deficiência e regulou o contrato de transporte em três seções: seção 1 - disposições gerais: arts. 730 a 733; seção 2 - transporte de pessoas: arts. 734 a 742; seção 3 transporte de coisas: arts. 743 a 756.

É. portanto, o contrato de transporte um contrato típico e que trata de assunto específico, isto é, o transporte terrestre. Por outro lado, continuam em vigor as leis esparsas sobre a matéria, que deverão ser também consideradas nos casos concretos, e é o que dispõe o art. 732 do Código Civil nos seguintes termos: "aos contratos de transporte, em geral, são aplicáveis, quando couber, desde que não contrariem as disposições deste Código, os preceitos constantes de legislação especial e de tratados e convenções internacionais"

O contrato de transporte, além de típico, é comutativo, bilateral, consensual (desde a compra da passagem está perfeito c acabado art. 740), de adesão e oneroso. ${ }^{55} \mathrm{O}$ novo Código Civil é expresso (art. 736) ao excluir das normas que regem contrato de transporte aquele feito gratuitamente por amizade ou cortesia. ${ }^{56} \mathrm{E}$ a Súmula n. 145 do STJ estabelece que "no transporte desinteressado, de simples cortesia, o transportador só scrá civilmente responsável por danos causados ao transportado quando incorrer em dolo ou culpa grave" E, somente nesse caso, caberá ao motorista do veículo

5. Dec.-lei n. 3.326/1941 - sobre transporte de malas postais; Dec. n. 1.832/199 - aprova o Regulamento dos Transportes Ferroviários; Lei n. 9.432/1997 - ordenação do transporte ferroviário; Dec. 11. 96.044/1998 aprova o regulamento para o transpone rodoviário de produtos perigosos. Súmulas: a) $187 /$ STF - "A responsabilidade contratual do 1 ransportador, pelo acidente com passageiro. não é elidida contra culpa de tcrceiro, contra o yual tem ação regressiva": b) 35/STF - "Em caso de acidentc do trabalho ou de transporte, a concubina tem direito de ser indenizada pela morte do amásio, se entre cles não havia impedimento para o matrimônio"; c) 491/STF - "É indenizavel o acidente que cause a morte de lílho menor, ainda que não exerça trabalho remunerado"; d) 161/STF - "Em contrato de transporte, é inoperante a cláusula de não indenizar". Além disso, tcmos as súmulas do STF n. 186 e 314, jả revogadas. O Código Comercial de 1850 continua regulando o transporte maritimo, que nessa parte continua em vigor.

55 A reserva de passagem é promessa de contratar e scu inadimplemento culposo se resolve em perdas e danos.

56 Art. 736, capur: "Não se subordina às normas do contrato de transportc o feito gratuitamente. por amizade ou cortesia" 
a obrigação de indenizar todos os prejuízos pessoais e patrimoniais sofridos pelo passageiro ("carona").

Por outro lado, o legislador no parágrafo único do mesmo dispositivo determina que "não se considera gratuito o transporte quando, embora feito sem remuneração, o transportador auferir vantagens indiretas" É o transporte aparentemente gratuito no qual o transportador tem interesse. A responsabilidade civil nesse tipo de transporte rege-se pelo Código Civil e pelo Código de Defesa do Consumidor. É o caso, por exemplo, do transporte "gratuito" dos empregados de uma empresa ou do transporte desinteressado do mecânico que vai passar o fím de semana na praia para consertar o motor do barco do seu hospedeiro ou mesmo do corretor de imóveis que leva o cliente em seu automóvel para que este possa ver e escolher qual desses imóveis irá comprar. ${ }^{57}$

Finalmente, o transportador, tanto de pessoas, quanto de coisas, tem obrigação de resultado, ${ }^{58}$ que é deslocar a pessoa ou a carga de um lugar para outro previamente determinado (destino) e tem também a obrigação de segurança (para alguns de garantia), que é a obrigação de transportar pessoas e coisas e desembarcá-las no lugar de destino incólumes. A chamada obrigação de incolumidade ou segurança é da essência do transporte e não pode ser excluída por acordo entre as partes. ${ }^{59}$

\subsubsection{A responsabilidade civil decorrente do transporte.}

A responsabilidade civil do transportador é fundamentada na teoria objetiva na vertente do risco da atividade. Seu fundamento está no art. 734 do Código Civil, portanto, basta o nexo causal entre o fato danoso sucedido durante o transporte e o prejuízo efetivo para que surja a obrigação de indenizar. $\mathrm{O}$ transportador assume o risco.

57 "Contrato de transporte - Presunçào de responsabilidade do transportador - Indenização por danos materiais e morais corretamente fixada - Quando o transportador tem algum interesse patrimonial no transporte, ainda que indireto, como ocorre no caso do transporte oferecido pelo patrão aos empregados para levá-los ao trabalho, nāo há que se falar em transporte benévolo, por isso que a gratuidade é meramente aparente. Nesse caso a responsabilidade do transportador é aquela decorrente das regras do contrato de transporte. Desprovimento do recurso (TJRJ - 2 Câm. Civel; AC n. 20.191/2000 - RJ; Rel. Des. Sérgio (avalieri Filho: j. 20/3/2001; v.u.).

8 Nesse sentido, segue acórdão do STJ: "Responsabilidade civil objetiva Vôo Internacional Atraso aplicação do $\mathrm{CDC}$. Se o fato ocorrcu na vigência do $\mathrm{CDC}$. a responsabilidade por atraso em vôo intemacional afasta a limitação tarifada da Convenção de Varsóvia (C.DC: arts. $6^{\circ}$, VI e 14). O contrato de transporte constitui obrigação de resultado. Nào basta que o transportador leve o transportado ao destino contratado. É necessário que o faça nos termos avençados (dia, horário. local de embarque e desembarque. acomodações, aeronave elc.). O Protocolo Adicional n. 03, $\mathrm{scm}$ vigência no direito internacional, não sc aplica no direito interno. A indenização deve ser fixada em moeda nacional (Decreto n. 97.505/98)" (STJ, RESP 151401/SP. Relator Ministro Humberto Gomes de Barros. Terceira Turma. julgado em 17/06/2004. publicado im 01/07/2004. Grifos nossos).

59 Nesse sentido. vide art. 51 do Código de Defesa do Consumidor, c Súmula 161 do STf. 
A sua responsabilidade está prevista na fattispecie legal, basta a adequação dos fatos à norma.

A excludente prevista em lei e que não faz atuar a responsabilidade do transportador pelos danos às pessoas transportadas e suas bagagens, é a força maior. $\mathrm{O}$ legislador não quis que o caso fortuito fosse excludente (arts. $734 \mathrm{e} 737$ ).

De fato, o Código Civil não coloca, como faz na parte contratual do mesmo diploma, o caso fortuito como excludente. Ou seja, apenas o fortuito externo ou as forças da natureza, os fatos incontroláveis, mesmo que previsíveis, os "acts of God" ou os "fatos do príncipe" serão capazes de elidir essa responsabilidade. O fortuito interno ou caso fortuito, que é o fato também necessário, cujos efeitos não era possivel evitar ou impedir (§ único do art. 393 do Código Civil), não atuará, pois ligado à pessoa ou à atividade do autor do dano. Como exemplo, temos o infarte sofrido pelo motorista do ônibus ou o assalto dentro do ônibus. ${ }^{60}$

Esses riscos devem ser absorvidos pelas empresas com fundamento na teoria do risco da atividade, por sinal, perigosa, o que permite o recurso também ao $\S$

60 "Processual civil e civil. Agravo no recurso especial. Transporte de mercadoria. Roubo. Responsabilidade da transportadora. O roubo de mercadoria praticado mediante ameaça exercida com arma de fogo é fato desconexo do contrato de transporte e, sendo inevitável, diante das cautelas exigiveis da transportadora, constitui-se em caso fortuito ou força maior, excluindo a responsabilidade dessa pelos danos causados. Agravo nāo provido" (STJ. AGRF.SP 470520/SP, Relatora Ministra Nancy Andrighi, Terceira Turma, julgado cm 26/06/2003. publicação em 25/08/2003). "Responsabilidadc Civil - Contrato de transporte Assalto. Embora tenha o transportador, em face do contrato de transporte, obrigação de levar o passagciro, são e salvo, até o seu destino, o assalto ao coletivo consubstancia fato de terceiro alheio ao transporte em si. rompendo a responsabilidade da transportadora. Não hả causalidade entre o assalto. fato estranho d̀ exploração do transporte. aos riscos normais deste, e o contrato de transporte, devendo, pois ser havido como fator excludente da responsabilidade da transportadora" (TJDF - RJEC n. 70/97 - Reg. Ac 94.178; rel. Des. Mário Machado - DJU 06.05.1997). "Indenização - Responsabilidade civil - Empresa de transporte coletivo - Dano sofrido por passageiro no interior do veiculo. em razão de assalto - Evento imprevisto e irresistivel - Ato de preposto não configurado - Verba não devida -.. Recurso não provido. Considera-se causa estranha ao transporte, equiparável ao caso fortuito, assalto praticado dentro do ônibus durante a viagem, quando tal incidente não for freqüente, o que exime a empresa transportadora do pagamento da indenização para ressarcimento de prejuizos sofridos pelos passageiros" (TJSP - 6 Câmara de Direito Privado; Ap. Cível n. 253.738-1 Osascu-SP; Rel. Des. Munhoz Soares; j. 30.05.1996; vu).

Em sentido contrário: "Responsabilidade Civil do Transportador. Assalto no interior de ônibus. Lesão irreversivel em passageiro. Recurso especial conhecido pcla divergência, mas desprovido pelas peculiaridades da espécie. Tendo se tornado fato comum e corriqueiro, sobretudo em determinadas cidades c zonas tidas como perigosas, o assalto no interior do ônibus já nāo pode mais ser genericamente qualificado como fato extraordinário e imprevisivel na execução do contrato de transporte, ensejando maior precaução por das empresas responsávcis por esse lipo de serviço, a fim de dar maior garantia e incolumidade aos passageiros. Recurso especial conhecido pela divergència, mas desprovido (STJ. RESP 232649/SP, Relator Ministro César Asfor Rocha, Quarta Turma, julgado em 15/08/2002, publicado em 30/06/2003). "Responsabilidade Civil - Morte de passageira em coletivo durante assalto Caso de força maior ou fortuito que não se consumaram, já que são previsiveis assaltos violentos a ònibus de passageiros. Não excluem da responsabilidade objetiva da transportadora o caso fortuito ou força maior. Obrigação da embargante à reparação dos danos causados pela mortc da vítima. Émbargos infring. $\mathbf{n}$. 20.781.4/6-01 Ribcirào Preto-SP: Rel. Des. Francisco Assis Vasconcelos Pereira da Silva: j. 04.11.1997; maioria de votos). 
único do art. 927 do Código Civil, no qual, apesar de não-previsto expressamente, teremos como excludentes a força maior (fortuito externo), a culpa exclusiva da vítima e o fato de terceiro desvinculado da atividade, o que equivale à força maior, como, por exemplo, a bala perdida que atinge o ônibus. $\mathrm{O} \S$ único do art. 927 contém. na verdade, as mesmas regras do art. 14 do Código de Defesa do Consumidor.

De outro lado, também é nula qualquer cláusula excludente de responsabilidade do transportador, sendo essa norma de ordem pública. O novo Código Civil, neste aspecto, recepcionou a súmula 161 do STF, nos mesmos termos. ${ }^{61}$

Todavia, dois problemas têm que ser enfrentados na hermenêutica da responsabilidade civil que emerge do "novo" contrato de transporte, que também é típica relação de consumo no seu sentido estrito e próprio. na qual sempre haverá um fornecedor de serviços e um consumidor final.

A primeira consideração diz respeito ao art. 735 do Código Civil, que expressamente determina que a responsabilidade contratual do transportador não é elidida por culpa de terceiro, contra o qual tem esse ação regressiva. no mesmo teor da Súmula n. 187 do STF. ${ }^{62}$

Ao mesmo tempo o Código de Defesa do Consumidor coloca como uma das excludentes da responsabilidade civil do prestador de serviços a culpa de terceiro. externo ao vínculo contratual (art. 14, $\S 3^{\circ}$. III, Código de Defesa do Consumidor).

Como conjuminar essa regras? Há antinomia entre elas?

Tenho dito em minhas aulas que neste "fato de terceiro" estão previstas duas situações diferentes. tanto é que no fato de terceiro, equivalente à força maior, não há como se propor ação regressiva contra o verdadeiro responsável. Explico melhor, o fato ou culpa de terceiro do art. 735. que não-elide a responsabilidade de transportador, é "aquele que com o transporte guarda conexidade, inserindo-se nos riscos próprios do deslocamento. O mesmo não se verifica quando intervenha fato inteiramente estranho, devendo-se o dano a causa alheia do transporte em si" ${ }^{\text {"3 }}$

Em suma, o fato de terceiro ligado ou conexo à atividade não exonera o transportador, como no caso de uma trombada de outro veículo (terceiro. causador do dano) no ônibus em que estava o passageiro, vítima do dano. Na hipótese, continuará a responsabilidade da empresa de ônibus, a qual poderá a posteriori entrar com ação regressiva, cobrando o quantum indenizatório contra o verdadeiro culpado.

\footnotetext{
${ }_{61}$ Súmula n. 161 do STF: "Em contrato de transporte, é inoperante a cláusula de não indenizar"

62 Súmula n. 187 do STF: "A responsabilidade contratual do transportador pelo acidente com passageiro. não é elidida por culpa de terceiro. contra o qual tem ação regressiva"

63 Conforme NERY, Nelson. Código Civil Anotado. São Paulo: Revista dos Tribunais. 2003. p. 444.
} 
É a mesma solução adotada no art. 188, II, que dispõe que não constitui ato ilícito a "deterioração ou destruição de coisa alheia, ou lesão a pessoa, a fim de remover perigo iminente." Porém, nos arts. 929 e 930. no capitulo que trata da obrigação de indenizar, temos prevista a indenização à vítima do dano ser paga pelo "benfeitor" que removeu perigo iminente salvando até a vida de alguém. Somente não recairá sobre ele a obrigação de indenizar se a pessoa lesada ou o dono da coisa foram culpados do perigo. A prova caberá ao autor do dano, dano esse que. segundo a lei, não teve origem no ato ilícito. Terá. de outro lado, o causador do dano ação regressiva contra o terceiro para haver a importância que tiver ressarcido ao lesado (Código Civil, art. 930, caput).

No que diz respeito ao suposto conflito de leis, podemos afirmar que não há antinomia entre a regra do Código de Defesa do Consumidor, que prevê a exoneração da responsabilidade por fato de terceiro externo à atividade do prestador de serviço e que vai atuar como excludente no contrato de transporte, e a regra do art. 735 do Código Civil, que responsabiliza o transportador quanto a fato de terceiro ligado diretamente à sua atividade. Em suma, são aplicados os dois diplomas legais, dependendo apenas do caso concreto.

Outro motivo de discussão, e talvez superposição de normas, é a regra do $\S$ único do art. 738 , que trata da redução eqüitativa da indenização, caso a vítima tenha concorrido para a ocorrência do dano e na medida dessa conduta. É a aplicação específica da regra geral prevista no art. 945, na parte da indenização, e que trata da concorrência de responsabilidades. Portanto, está na sistemática do novo Código Civil a chamada culpa concorrente, que tem como critério a gravidade das culpas, ou seja. também deverá ser levado em conta os graus de culpa, pois é o que dispõe o art. 945, que é expresso ao determinar que se a vitima tiver concorrido culposamente para o evento danoso, a sua indenização será fixada tendo-se em conta a gravidade da culpa em confronto com o autor do dano.":

A dúvida hermenêutica que pode aparecer é se ao contrato de transporte também se aplica a culpa exclusiva da vítima. que é excludente da responsabilidade do prestador de serviços no Código de Defesa do Consumidor, tendo em vista ser o transporte também relação de consumo: ou se somente se aplicará a culpa concorrente especifica do transporte. ${ }^{65}$

64 O art. 944, cuput. dispõc que a indenização mede-se pela extensão do dano. Porćm. essa regra sofre uma ressalva, que é talvez uma das mais polèmicas e importantes inovaçōes dentro do Código Civil. Ou seja, p parágrafo único do dispositivo determina que "se houver excessiva desproporçào entre a gravidade da culpa e o dano poderá o juiz reduzir. eqüitativamente, a indenização" Dessa forma, voltamos ao criterio dos graus de culpa, quais sejam. culpa grave, leve e levíssima.

65. "Indenização - Acidente de trânsito - Empresa de transporte coletivo - Pingente - Morte - Pensão J imitc de idade - Décimo terceiro salário - Dano moral Culpa concorrente. Em se tratando de acidente 
Penso que a solução é mais simples do que possa aparecer, e não há antinomia entre os dois sistemas. O contrato de transporte é lei especial, além de ser lei mais nova que o Código de Defesa do Consumidor. Portanto, o legislador quis dar especialidade ao transporte (a lei especial derroga a lei geral), apesar de ser também relação de consumo. Assim, penso que a interpretação correta é no sentido de aplicar-se primeiro o Código Civil e também o Código de Defesa do Consumidor, como norma complementar e protetiva.

Em outras palavras, vão operar como excludentes da responsabilidade civil por danos no transporte: a força maior, que é duas vezes mencionada no Código Civil (arts. 734 e art. 737), estando excluido o caso fortuito por ser a responsabilidade do transportador fundada no risco da atividade perigosa. Também serão excludentes a culpa exclusiva da vítima e o fato de terceiro externo ao vínculo contratual (Código de Defesa do Consumidor, art. 14, $\S 3^{\circ}$, II). Além disso, dependendo do caso concreto, poderá o transportador pedir ao juiz a redução eqüitativa da indenização, na medida em que a vítima houver concorrido para a ocorrência do dano. Portanto, haverá uma atenuação (não uma excludente) da indenização no caso. Nos casos resolvidos, somente com o Código de Defesa do Consumidor, não é possível a aplicação da culpa concorrente, somente da culpa exclusiva da vítima. Na relação de consumo ou há responsabilidade total (mesmo que a vítima do acidente de consumo concorra para isso) do fornecedor ou-

\footnotetext{
de trânsito decorrente da queda de menor. pingente em porta de colctivo. fato que poderia ter sido evitado pelo condutor do ônibus, ao observar a atitude daquele, é devida a indenização por dano material, mediante pensionamento aos pais da vitima, não cabendo, entretanto, reparação por dano moral, uma vez que esta concorreu culposamente para o evento danoso. A Indenização por pensionamento deve se estender atć a data em que a vitima viesse a completar 65 anos de idade. sendo inaceitável a presunção de que, a partir dos 25 anos de idade, não mais contribuiria com o sustento dos pais. No pensionamento deve scr incluido o $13^{\circ}$ salário, em atendimento ao princípio de que a indenização por ato ilícito, ainda mais em caso de morte, deve ser a mais ampla possivel" (TAMG - 4a (âm. Civil: Ap. Civel n. 225.657-9-Belo Horizonte-MG; Rel. Juiz Ferreira Esteves; j. 18.12.1996; v.u.).

"Responsabilidade Civil - Acidente de Trânsito - Pretensão da autora ao reconhecimento da teoria objetiva da empresa-ré - Inadmissibilidade - Existència de prova da ocorrència de culpa da vitima que veio a se chocar com o coletivo da ré quando este encontrava-se parado no semáforo não sc justificando a prevalência da responsabilidade pretendida. Indenizatória improcente - Recurso improvido. Responsabilidade civil. Atropelamento e morte. Responsabilidade objetiva. Atenuação c exclusão

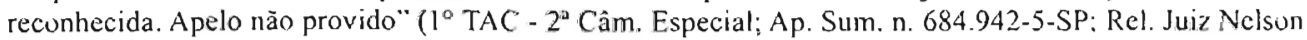
Ferreira: j. 20.08.1996; v.u.).

"Responsabilidade civil Acidente de trânsito - Vítima fatal - Passageiro de ônibus que. ao procurar descer do mesmo, bateu a cabeça num poste e faleceu em virtude das lesões sofridas - Inexistência de prova de culpa do motorista, sendo que o fato ocorreu já fora do conduzido cstando este parado Responsabilidade objetiva excluído quando o fato se dá por conta exclusiva do próprio ofendido Indenizatória improcedente - Recurso improvido" (1 ${ }^{\circ}$ TAC - $8^{3}$ Câm. A; Ap. n. 633.862-3-SP; Rel. Juiz Mauricio Ferreira Leite; j. 22.11.1995: v.u.).
} 
não há nenhuma responsabilidade, pois o liame causal nem se formou por culpa exclusiva da vítima. ${ }^{60}$

Em suma, a teoria do risco, que fundamenta a responsabilidade civil do transportador, é o que a Doutrina tem chamado de teoria do risco mitigada, porquanto admite, como vimos, a atuação das excludentes.

7. Da previsão e da avaliação do dano moral

A indenização por dano moral, como dano extrapatrimonial puro, era concedida timidamente até a Constituição Federal, de 1988, que expressamente tutelou e garantiu esse tipo de ressarcimento como um dos direitos e garantias fundamentais (art. $5^{\circ}, \mathrm{V}$ e X).

Em seguida, com a promulgação do Código de Defesa do Consumidor (Lei n. 8.078 de 11/09/1990) o dano moral tomou a expressão protetiva do consumidor, que nas indenizações pelos defeitos do produto e do serviço passam a incluir verba especifica para compensação do dano moral sofrido por ocasião da relação de consumo. De fato, conforme o art. $6^{\circ}$ desse Diploma, são direitos básicos do consumidor, além da proteção à vida, saúde e segurança contra os riscos do fornecimento de produtos e serviços, a educação e informação adequada sobre os diferentes produtos e serviços etc, "a efetiva prevenção e reparação de danos patrimoniais e morais, individuais, coletivos e

$\therefore$ "Direito Civil. Responsabilidade Civil. Transporte coletivo. Bala perdida. Fato de terceiro. Bala perdida não é fato conexo aos riscos inerentes do deslocamento. mas constitui evento alheio ao contrato de transporte. não implicando responsabilidade da transportadora. Recurso especial parcialmente conhecido e, nesta extensão, provido" (STJ, RESP 613402/SP, Relator Ministro César Asfor Rocha, Quarta Turma. Julgado em 15/04/2002. publicado em 04// 0/2004).

"Direito Civil. Responsabilidade Civil. Explosão de bumba em composição ferroviária. Fato de terceiro. Caso fortuito. O depósito de artefato explosivo na composição ferroviaria por terceiro não é fato conexo aos riscos inerentes do deslocamento, mas constitui evento alhcio ao contrato de transportc, não implicando responsabilidade da transportadora. Recurso especial não conhecido (STJ, RESP 589051/SP, Relator Ministro César Asfor Rocha, Quarta Turma. julgado em 23/03/2004, publicado em 13/09/2004).

"Responsabilidade Civil Transporte de passageiros Arremesso de objeto para o interior do veículo Lisão em passageiro - Fato de terceiro excludente de responsabilidade - Precedentes. I - A presunção de culpa da transportadora pode ser ilidida pela prova de ocortência de fato de terceiro, comprovadas a atenção e cautela a que está obrigada no cumprimento do contrato de transporte a empresa. II O arremesso de objeto. de fora para dentro do veiculo. não guarda conexidade com a atividade normal do transportador. Sendo ato de terceiro. exclui a responsabilidade do transportador pelo dano causado an passageiro. Precedentes. Recurso Especial provido" (STJ. RESP, 231137/RS. Relator Ministro Castro Filho, julgado em 29/10/2003. publicado em 17:11:2003). 
difusos" ${ }^{67}$ conforme previsto no inciso VI do art. $6^{\circ}$ do Código de Defesa do Consumidor.

Dessa forma, se o contrato é de consumo (por exemplo, compra de automóvel, geladeira, pacote turístico) o consumidor vai pedir ou a troca do produto ou a indenização patrimonial correspondente, mais uma parcela a título de dano moral pelo constrangimento sofrido. Tornou-se prática diuturna.

A indenização do dano moral está expressamente prevista no art. 186 do Código Civil, cláusula geral indenizatória, no qual vem determinada a reparação do dano ainda que exclusivamente moral.

O ressarcimento do dano moral também vem sendo admitido nas relações contratuais (mesmo aquelas que não são de consumo). Há farta jurisprudência, inclusive anterior à promulgação do novo Código Civil. Essa indenização é de caráter extracontratual (apesar do evento danoso ser contratual) e aparece "a lattere" dos deveres

67 O dano moral coletivo é desde então admitido em nosso Direito. Conforme BITTAR, Carlos Alberto. O dano moral coletivo no atual contexto juridico brasileiro. Revista de Direito do Consumidor, São Paulo, v. 12, p. 44, 1994; VENTURI, Elton. Responsabilidade Civil por danos causados aos direitos difusos e coletivos. Revista de Direito do Consumidor, São Paulo, v. 15, p. 79, 1995; JORGE, Flávio Chaim. Responsabilidade Civil por danos coletivos sobre a ótica do consumidor. Revista de Direito do Consumidor, São Paulo, v. 17, p. 97, 1996.

Há também alguns acórdãos sobre dano moral coletivo: "Processo Civil. Ação Civil Pública. Declaração de Inconstitucionalidade. Legitimidade Ativa do Ministério Público reconhecida. Precedentes desta corte. 1. (...) 2. In casu, o pedido de Ação é para afastar a restrição de prazo de validade de 90 dias para utilização dos créditos adquiridos através de cartões pré-pagos pelos consumidores usuários do serviço de telefonia celular pré-pago. O outro pedido é para que as concessionárias do serviço de telefonia celular sejam condenadas a pagar indenização por danos morais coletivos. causados ao grupo social de consumidores usuários do serviço celular pré-pago. 3. A declaração incidental de inconstitucionalidade da Norma 03/98 é causa de pedir. Os pedidos decorrem da fundamentação, sendo que, no caso especifico de controle difuso da constitucionalidade das leis. em sendo prejudicial do mérito, a referida declaração é destacada por motivos técnicos também quando da elaboração do pedido. A declaração de inconstitucionalidade no contexto dos autos nào pode scr vista como integrante do pedido principal. 4. (...) 7. Recurso especial provido" (STJ, RESP 623325/GO, Relator Ministro José Delgado, Primeira Turma, julgado em 28/09/2004, publicado em 08.11.2004).

"Ação Civil Pública. Dano Ambiental de Dano Moral Coletivo. Competência Recursal. Apreciação de recurso decorrente de ação civil pública, promovida pelo Ministério Público perante a Justiça Estadual, onde busca o ressarcimento por dano ambiental e dano moral coletivo, em face da Companhia Nacional de Abastecimento-CONAB, Empresa Pública Federal, refoge a competència do Tribunal de Justiça do Estado. Competència declinada para o Tribunal Regional Federal da Quarta Regiāo" (Apelação civel n. 597068089. Primeira Càmara Cível, Tribunal de Justiça do RS. relator: Leo Lima, julgado em 25/03/1998).

“Ação Civil Pública. Ministério Público. Ònus sucumbenciais. Isenção. Pedido de cessação de atividades Sonoras e de indenização. Cumulação. Descabimento. Pedidos Alternativos. 1 No ajuizamentu da ação civil pública, descabe a cumulação de pedidos relativos à cessaçào das atividades sonoras, e de indenização por dano moral coletivo. de acordo com a previsão contida no ant. 3, da Lei n. 7.347/85. Pretensões alternativas. Sendo acolhido um dos pedidos resta prejudicada a outra pretensão. 2- $O$ aforamento de ação civil pública e função institucional do Ministério Público, não sendo cabivel a sua condenação aos ònus sucumbenciais, salvo de existente prova a atestar a má-fé. Apelo provido em parte" (Apelação ('ivel n. 599368768, Décima Primeira Câmara Cível, Tribunal de Justiça do Rio Grande do Sul. Relator Paulo Antònio Kretzmann, julgado em 29/06/2000). 
tipicamente contratuais. São conseqüências ulteriores, para além do contrato, que levam à cumulação da responsabilidade contratual e extracontratual,${ }^{68}$ como o atraso na entrega de um imóvel que gera angústias e frustração de expectativas e sonhos. Fique claro que o mero aborrecimento não leva a prejuízo moral. ${ }^{69}$

Ramón Daniel Pizarro observa que "um fato ilícito não deixa de ser tal, nem modifica sua natureza, pela mera circunstância de produzir-se 'dentro' de uma obrigação pré-existente que resulta descumprida ou 'fora' dela" ${ }^{70}$ Como bem observa André Gustavo Correia de Andrade fundamental nesta matéria é a distinção entre a patrimonialidade da prestação e a extrapatrimonialidade do interesse do credor ou dos bens afetados (grifos nossos). ${ }^{71}$

Também podem gerar danos morais os atos abusivos de uma parte no prejuizo da outra apesar de acabar cumprindo as obrigações assumidas contratualmente. Nesse caso e com fundamento nos arts. 186 e 187 caberá indenização por ato ilícito, ainda que simplesmente moral. Essa abusividade é diuturna da parte de certos fornecedores principalmente nos serviços levando o consumidor ao "stresse" causado pela tal "canseira", que não passa de exercício abusivo do direito.

$\mathrm{O}$ ressarcimento do dano moral às pessoas jurídicas, consagrado em jurisprudência torrencial, tem por fundamento a lesão à honra objetiva das empresas. ${ }^{72}$ É

6. Apesar de nosso Direito Civil separar a responsabilidade contratual da extracontratual, na verdade a responsabilidade contratual nasce do inadimplemento e tem a função de execução obrigatória do contrato. $\dot{\mathrm{E}}$ modo de pagamento forçado acrescido de perdas e danos. Ao contrário, a responsabilidade extracontratual é sanção (obrigação de indenizar) ao ato ilícito; ver para essa matéria REMY. Philippe. La responsabilité contractuelle: histoire d'un faux concept. R. T. de Droit Civil, Paris, n. 2, p. 323-355. abriljunho, 1997.

69 Jornadas III Enunciado 159 STJ: "O dano moral, assim compreendido todo dano extrapatrimonial, não se caracteriza yuando há mero aborrecimentu inerente ao prejuízo material"

70 Apud A.NDRADE, André Gustavo Correia de. Dano moral em caso de descumprimento de obrigação contratual. Amaerj Noticias Especial 20. Disponivel em: <http://www.amaerj.org.br >. Acesso em: 10 out. 2006.

71 Apud ANDRADE, André Gustavo Corrcia de. Op. cit.

72 "Dano moral. Pessoa juridica. Prova do dano. Protesto indevido de título. Súmula n. 227 da Corte. 1. Istá alinhada a jurisprudência da Corte no sentido de que a pessoa jurídica pode sofrer dano moral (Súmula $\mathrm{n}$. $227 \mathrm{da}$ Corte). 2. Provado u lato gerador do danu mural, no caso, o indevido protesto, impòe-se deferir a indenização. 3. Recurso especial conhecido e provido" (STJ, RESP 538/RS, Relator Ministro Carlos Alberto Menezes Direito, Terceira Turma, julgado em 16/12/2003, publicado cm 29/03/2004. Grifos nossos).

"Dano moral. Pcssoa juridica. Pcrdas e danos. Prova. Súmulas ns. 07 e 227 da Corte. Precedentes. 1. ఏáa assentou a Corte, com a Súmula n. 227, yue a pessoa juridica pode sofrer dano moral. 2. Provado o fato causador do dano moral. assim o indevido protesto do título, cabivel é a indenização. 3. Afastada pelo Acórdão recorrido a indenização por perdas c danos, diante da ausência de prova, a Súmula n. 07 da Corte impede o curso do especial no ponto. 4. Recurso especial conlucido e provido. em parte" (STJ, RESP 312689/SP. Relator Ministro Carlos Alberto Menezes Dircilo. Terceira Turma, julgado em 18/09/200l. publicado em 29/10/2001. Grifos nossos.).

"Civil - Ação de Indenização - Responsabilidade Civil - Pessoa Juridica - Dano Moral. I - A honra objetiva da pessoa juridica pode ser ofendida pelo protesto indevido de titulo cambial. ( abivel a ação de 
oportuno lembrar-se que, mesmo antes do Código Civil, já tínhamos a Súmula n. 227 do STJ que declarava que "a pessoa jurídica pode sofrer dano moral" Porém, essa proteção foi cabal com a entrada em vigor do novo Código Civil, que em seu art. 52 dispõe que se aplica às pessoas jurídicas, "no que couber, a proteção dos direitos da personalidade"

Contudo, o grande problema nesse tema continua sendo a avaliação do quantum que deve ser pago a título de dano moral. Como bem esclarece Ruy Rosado de Aguiar Júnior." "não temos leis que estabeleçam critérios ou parâmetros para a fixação de dano; todas as disposições que tinhamos quanto à indenização por danos morais foram afastadas depois da Constituição de 1988, que veio garantir a indenização pelo dano moral" (grifos nossos).

Dessa forma, o que vemos é uma jurisprudência titubeante que para fatos iguais estabelece indenizações completamente diferentes. Hoje, no Brasil, não existe limitação legal ao quantum indenizatório do dano moral. Dá-se a quantia que compense os sofrimentos, constrangimentos e humilhações advindos daquele fato específico ${ }^{74} \mathrm{Sem}$ dúvida, a partir da Constituição Federal, de 1988, instalou-se a indústria da indenização do dano moral (reforçada pelo Código de Defesa do Consumidor) e criou-se com isso grande insegurança social, pois os profissionais liberais e as empresas, mas também os particulares que venham a ser réus em ação de indenização, nunca saberão se ficarão na pobreza após o ocorrido.

Todavia. penso que já estamos em "correção de rota" e que nossos tribunais já estão examinando melhor os pedidos infundados ou as indenizações absurdas. porque astronômicas. A eqüidade é a regra de interpretação e fixação da indenização por dano moral. Aliás, o juiz vai sempre julgar por arbitramento ou por artigos, pois o art. 946 do Código Civil remete para a lei processual a apuração do valor das perdas e danos, quando a obrigação for indeterminada e não houver na lei ou no contrato disposição fixando a indenização. O antigo Código Civil continha regra semelhante. porquanto estabelecia que não havendo previsão no Código Civil a liquidação da indenização devia ser feita por arbitramento (art. I.553, do Código Civil,

indeni<ação, por dano moral, sofrido por pessoa jurídica, visto que a proteção dos atributos morais da personalidade não está reservada somente às pessoas fisicas (REsp n. 60.033-2-MG-DJ de 27/11/95). I1Recurso conhecido e provido" (STJ, RESP 147702/MA, Relator Ministro Waldemar Zveiter, Terceira Turma. julgado em 21/11/1997, publicado em 05/04/1999. Grifos nossos.).

AGUIAR JÚNIOR, Ruy Rosado de. O Novo Código (ivil e o Código de Defesa do Consumidor (pontos de convergência). Revista EMERJ. Rio de Janciro, v. 6, n. 24, p. 26, 2003.

is Tem sido pacificamente admitida pela Jurisprudencia e Doutrina brasileiras a dupla função da indenização por dano moral, quais sejam, a compensatória e a punitiva, chamada de "valor de desestímulo" (expressão cunhada por Carlos Alberto Bittar). Em muitos casos a indenização exemplar é mais pesada que a compensatoria. 
de 1916). Evidentemente, tanto numa lei, quanto na outra, o julgamento se fundamenta na eqüidade.

O novo Código Civil contém regras expressas autorizando o critério da eqüidade pelo juiz. Pode ser lembrado o parágrafo único do art. 944, que determina que o juiz poderá reduzir equiitativamente a indenização, se houver excessiva desproporção entre a gravidade da culpa e o dano, como vimos. Mas, o fundamento melhor para o julgamento pela eqüidade está no art. 953 que trata da indenização por injúria, difamação e calúnia e que em seu $\S$ único determina que "Se o ofendido não puder provar prejuízo material, caberá ao juiz tixxar, eqüitativamente, o valor da indenização, na conformidade das circunstâncias do caso"

Em resumo, o dano moral puro é efetivamente ressarcido no Direito brasileiro (art. 186 do (C), além de ser uma garantia constitucional (art. $5^{\circ}, \mathrm{V}$ e X), estando prevista sua fixação pelo prudente arbítrio do juiz, que deverá usar da justiça do caso concreto, mesmo porque não há outro critério em nosso ordenamento. Essa é a solução que vem sendo dada nas últimas décadas ao problema da avaliação e fixação do quantum indenizatório a título de dano moral. ${ }^{75}$

\section{Conclusão}

Sem dúvida, apesar da culpa continuar sendo a regra geral da responsabilidade civil no Direito brasileiro, estamos diante de um processo cada vez mais rápido de objetivação dos fundamentos da reparação civil em nosso País. Isso é o que se pode averiguar não-só nos vários dispositivos do Código, de 2002, e leis especiais, mas, principalmente, pela adoção da cláusula geral que prevê o ressarcimento dos danos para todos os casos de atividades que ponham em risco, por sua natureza, os direitos de outrem (parágrafo único do art. 927).

Sobre dano moral v. AZEVEDO, Antonio Junqueira de. Estudos e pareceres de direilo privado. São Paulo: Saraiva, 2004. p. 291 e segs.; AMARANTE, Aparccido. Responsabilidade civil por dano à honra. 2. ed. Belo Horizonte: Ed. Del Rey, 1994; BREBBIA, Roberto H. El daño moral. 2. ed. Rosario (Argentina): Ed. Urbir, 1967; SILVA, Wilson Melo da. O dano moral e sua reparação. 2. ed. Rio de Janeiro/São Paulo: Forense, 1969; MINOZZI, Alfredo. Danno non palrimoniule. 3. ed. Milão: Societa Editrice Libreria, 1917; RAVAZZONE, Alberto. La riparazione del danno non patrimoniale. Milāo: Ed. Giuffrè, 1962; SEVERO, Sèrgio. Os danos extrapatrimoniais. São Paulo: Saraiva, 1996; REIS, Clayton. Avaliação do dano moral. Rio de Janeiro/São Paulo: Forense, 1998; THEODORO JÚNIOR, Humberto. Dano moral. São Paulo: Ed. Oliveira Mendes, 1998; BENASSE, Paulo Roberto. A personalidade, os danos morais e sua liquidação de forma múltipla. Rio de Janeiro/São Paulo: Forense, 2003; CAHALl, Yussef Said. Dano moral. 2. ed. São Paulo: Revista dos Tribunais, 1998; DONNINI. Odivaldo; DONNINI, Rogério Ferraz. Imprensa livre, dano moral. dano à imagem e sua quantificação à luz do novo código civil. São Paulo: Método Editora, 2002; LOPEZ, Teresa Ancona Dano estético. 3. ed. atual. com o Código Civil de 2002. São Paulo: Revista dos Tribunais, 2004. 
De outro lado, há nítida tendência de acolhimento da doutrina da responsabilidade civil preventiva ${ }^{76}$ já prestigiada na França, nos Estados Unidos da América, na Itália (que tira seu fundamento da Constituição) e aqui no Brasil, por meio das tutelas processuais ressarcitórias e antecipatórias, que têm como finalidade a proteção dos interesses difusos, com destaque na área do consumidor e na área ambiental. Para a efetiva proteção e prevenção de danos coletivos e sociais temos a importante Lei da Ação Civil Pública, ${ }^{77}$ que coloca os membros do Ministério Público como instrumentos indispensáveis para essa efetiva prevenção, como nas hipóteses de proteção ao meio ambiente, evitando, assim, o efetivo dano ambiental.

Porém, a possibilidade de nascer a obrigação de indenizar somente pelo risco criado sem a existência de dano, como é o caso da responsabilidade civil preventiva, somente deve ser admitida em casos de riscos extremos que ponham em perigo a própria sobrevivência da sociedade e até mesmo do planeta, ou seja, previne-se a manutenção da própria vida. ${ }^{78}$

São Paulo, dezembro de 2006.

Referências

AGUIAR JÚNIOR, Ruy Rosado de. O Novo Código Civil e o Código de Defesa do Consumidor (pontos de convergência). Revista EMERJ, Rio de Janeiro, v. 6, n. 24, 2003.

AMARANTE, Aparecido. Responsabilidade Civil por Dano à Honra. 2. ed. Belo Horizonte (Brasil): Ed. Del Rey, 1994.

ANDRADE, André Gustavo Correia de. Dano moral em caso de descumprimento de obrigação contratual. Amaerj Noticias Especial 20. Disponivel em <www.amaerj.org.br>. Acessado em: 10 outubro 2006.

ASCARELLI, Tullio. Corso di diritto commerciale. 3. ed. Milão: 1962.

${ }_{76}$ Adela M. Segui define a responsabilidade preventiva como: "La responsabilidad, enfocada desde esta nueva expresión de la prevención, adopla una acepción y de antecipación y de previsión de lo nocivo potencialmente incierlo e introduce una nueva dimensión: no se trala ya de reparar un daño sino un riesgo. Su rol ha cambiado" SEGUI, Adela M. Aspectos relcvantes de la responsabilidad civil moderna. Revista do Direito do Consumidor, São Paulo, v. 13, n. 52, p. 267-346, 2004. p. 310; THIBIERGE, Catherine. I.ibres propôs sur l'evolution du droit de la responsabilité. Revue Timestrielle de Droit Civil, $\mathrm{n}$. 3, Paris, 1999.

77 Lei n. 7.347, de 24 de julho de 1985.

78 O Código de Defesa do Consumidor, admitindo a punição à publicidade enganosa, está adotando a responsabilidade sem dano. Em outras palavras, aquele que veicula esse tipo de publicidade esta obrigado à reparaçàn pelo risco de enganosidade criado. mesmo que não haja vítimas. 
AZEVEDO, Antonio Junqueira de. Estudos e pareceres de direito privado. São Paulo: Saraiva, 2004.

BENASSE, Paulo Roberto. A personalidade, os dunos morais e sua liquidaçâo de forma múltipla. Rio de Janeiro'São Paulo: Forense, 2003.

BITTAR, Carlos Alberto. O dano moral coletivo no atual contexto juridico brasileiro. Revista de Direilo do Consumidor, São Paulo, v. 12, 1994.

BREBBIA, Roberto H. El daño moral. 2. ed. Rosario (Argentina): Ed. Orbir, 1967.

BULGAREI.LI, Waldírio. A teoria juridica de empresa. Tese para provimento de cargo de Professor Titular de Direito Comercial da Faculdade de Direito da Universidade de São Paulo, São Paulo, 1984.

CAHALI, Yussef Said. Dano moral. 2. ed. São Paulo: Revista dos Tribunais. 1998.

CARPENA, Heloísa. Abuso de direito nos contratos de consumo. Rio de Janeiro/São Paulo: Renovar, 200 l.

CAVALIERI Filho, Sergio. Responsabilidade civil no Novo Código Civil. Revista da EMERJ. v. 6 , ก. 24.

DONNINI, Odivaldo; DONVIN], Rogério Ferraz. Imprensa livre, dano moral, dano à imagem e sua quantificação à luz do Novo Código Civil. São Paulo: Método Editora, 2002.

GOMES, Orlando. Introdução ao Direito Civil. 12. ed. Rio de Janeiro: Forense, 1996.

IURGE, Flávio Chaim. Responsabilidade civil por danos coletivos sobre a ótica do consumidor. Rcvista de Direiro do Consumidor; São Paulo, v. 17, 1996.

LEVANTI, Sandra. Abuso del diritto. Diritto e Diritti Portale Giuridico, junho 200I. Consulta em $21,05 / 2004$.

LIMA, F. A. Pires de; VARELA, J. M. Antunes. Código civil anotado. Portugal: ('oimbra Editora Ltda., 1967. v. 1.

LOPEZ, Teresa Ancona. Comentários ao código civil. São Paulo: Saraiva. 2003. v. 7.

LOPEZ, Teresa Ancona. Dano Estético. 3. ed. atual. com o Código Civil de 2002. São Paulo: Revista dos Tribunais. 2004.

MAFFEIS, Marta Rodrigues. Contribuição do estudo da responsabilidade cıvil do médico à luz do direito romano. 2004. Tese (Doutorado) - Faculdade de Direito da USP, São Paulo. 
MARQL'ES, Cláudia Lima. Contratos no código de defesa do consumidor. 4. ed. São Paulo: Revista dos Tribunais, 2002.

MINOZZI, Alfredo. Dunno non putrimoniale. 3. ed. Milão: Società Editrice Libruria. 1917.

NERY, Nelson. Código civil anolado e legislação exiravagant. 2. ed. São Paulo: Revista dos Tribunais, 2003.

. Código de defesa do consumidor comentado pelos autores. 6. ed. Rio de Janeiro: Forense, 1999.

PANNUCCIO. Vicenzo. Teoria giuridica dell'Impresa. Milão, 1974.

PATTI, Salvatore.(Trad.). Códice Civile Tedesco. Milão: Ed. Giuffrè, 2005.

POGLIANI, Mario. Responsabilità e rissarcimento da illecito civile. Milão: Ed. Giuffrè, 1969.

RAVAZ7.ONE. Alberto. La riparazione del danno non patrimoniale. Milão: Ed. Giuffrè, 1962.

RECANO, Paolo. La responsabilità civile da attività pericolose. Padova: Fd. Cedam, 2001.

REIS, Clayton. Avaliação do dano moral. Rio de Janeiro/São Paulo: Forense, 1998.

REMY. Philippe. La "responsabilité contractuelle": histoire d'un faux concept. Revue Trimestrielle de Droil Civil. Paris. v. 96, n. 2, abril-junho. 1997.

RODRIGUES, Silvio. Direito civil Responsabilidade civil. 19. ed. São Paulo: Ed. Saraiva, 2002. v. 4.

SEGUl, Adela M. Aspectos relevantes de la responsabilidad civil moderna. Revista do Direito do C'onsumidor; São Paulo, v.13. n.52.p.267-318. out./dez. 2004.

SEVERO, Sérgio. Os danos extrapatrimoniais. São Paulo: Saraiva, 1996.

SILVA, Wilson Melo da. O dano moral e sua reparaşào. 2. ed. Rio de Janeiro/São Paulo: Forense, 1969.

SODRÉ, Marcelo Gomes. As leis principiológicas de defesa do consumidor na América Latina: origens, importância e principais disposições. 2000. Dissertação (Mestrado) - Pontificia Universidade C.atólica. São Paulo. 2 v.

STOCO, Rui. Tiutudo de responsabilidade civil. 5. ed. São Paulo: Revista dos Tribunais, 2001.

THEODORO JUNIOR, Humberto. Lano moral. São Paulo: Fd. Oliveira Mendes, 1998.

THIBIERGE, Catherine. Libres propôs sur l'evolution du droit de la responsabilité. Revuc' Timestrielle de Droit Civil. n. 3, Paris, 1999. 
VENTURI, Elton. Responsabilidade civil por danos causados aos direitos difusos e coletivos. Revista de Direito do Consumidor, v. 15, São Paulo, 1995.

VISINTINI, Giovanna. Trattato breve della responsabilità civile. 2. ed. Padova: Cedam, 1999. 